Fátima Lima, Manuel Lopes Nunes, Jorge Cunha, André F.P. Lucena, Driving forces for aggregate energy consumption: A cross-country approach, Renewable and Sustainable Energy Reviews, Volume 68, Part 2, February 2017, Pages 1033-1050, ISSN 1364-0321, http://dx.doi.org/10.1016/j.rser.2016.08.009.

(http://www.sciencedirect.com/science/article/pii/s13640321163 04178)

\title{
Driving forces for aggregate energy consumption: A Cross-country approach
}

\author{
Fátima Lima ${ }^{1}$, Manuel Lopes Nunes ${ }^{1}$, Jorge Cunha ${ }^{1 *}$, \\ ${ }^{1}$ ALGORITMI Research Centre, \\ University of Minho, Portugal \\ *Corresponding author. E-mail: jscunha@dps.uminho.pt \\ André F P Lucena ${ }^{2}$ \\ ${ }^{2}$ PPE/COPPE, Universidade Federal do Rio de Janeiro, \\ Rio de Janeiro, Brasil \\ e-mail: andrelucena@ppe.ufrj.br
}

\begin{abstract}
Although a cornerstone for development, past and current energy use has often posed a major challenge for policymakers with respect to planning and management. Within this context, in this paper an updated multi-sectorial cross-country assessment of energy consumption trends was undertaken, aiming at identifying the main drivers of changes in aggregate energy consumption. These drivers have been interpreted in the light of the policy measures that have been implemented over the years by different countries to achieve a sustainable development of the energy sector. The cross-country assessment encompasses a set of developed (United Kingdom, Portugal and Spain) and emerging (Brazil, China, and India) countries. Resorting to the Logarithmic Mean Divisia Index (LMDI) decomposition method, changes in the aggregate energy consumption were decomposed into three main explanatory effects: activity, structure and intensity. The major findings achieved reflect the relevance of intensity and activity effects in detriment of the structural effect. The assessment of energy consumption trends using the LMDI decomposition method provides critical information regarding which is the dominant factor that should be focused in policy design.
\end{abstract}

\section{KEYWORDS}

LMDI decomposition, energy consumption, energy policy, energy sustainability

\section{Introduction}

Although a cornerstone for development, past and current energy use has often contributed to an imbalance of socioeconomic and environmental dimensions of sustainability. This resulted in a significant challenge for policymakers with respect to energy planning and management. As the multi-dimensional implications of unsustainable use of energy become further exposed [1], the need to develop and promote policies, which reinforce resource and 'eco-economic' 
decoupling [2], [3], while fostering environmental improvements, become relevant. In this context, alternatives, such as the improvement of energy efficiency and the incorporation of renewable energy sources (RES) in a country's energy system, have become increasingly used both at national and international levels. In fact, the need to make this transition in order to avoid risks for both human and natural ecosystems prompted by climate change has been emphasised by [4]. The role and relevance of RES in different countries has experienced a significant growth, driven by such concerns. The rapid evolution and significant contribution of various renewable technologies for the fulfilment of targets either at national and/or international level has been reported for developed and emerging countries. Technical and policy aspects of wind power integration in Ireland and United Kingdom have been reviewed by [5] and [6]. Within European Union's (EU's) policy framework for RES, progress of the contribution of renewable energy alternatives for energy supply has been assessed by [7] and [8]. Contribution of RES initiatives for the energy sector were also reviewed in the context of the national action plan on climate change for India [9]. Technical, political and social aspects were also taken into consideration to assess the increase in integration of wind power in the Brazilian energy matrix [10].The contribution of wind power sector and its environmental benefits for the energy sector in China, has been assessed by [11].

The multidimensional benefits of these alternatives contribute to conciliate conflicting interactions between energy and socioeconomic and environmental dimensions, as emphasised by [11] within a country, and [12], [13] on a cross- country context. Therefore, assessment of energy and energy- related issues are extremely relevant, within policy decision-making context, to ensure future sustainability. This view is increasingly recognised through multiplicity of international initiatives undertaken, such as Millennium Development Goals ${ }^{1}$. Within this context, in this article an updated (1990-2012) multi-sectorial cross-country assessment of energy consumption trends was undertaken, aiming at identifying the main drivers of changes in aggregate energy consumption. These drivers have been interpreted in the light of the policy measures that have been implemented over the years by different countries to achieve a sustainable development of the energy sector. It was evaluated if overall trends are consistent with or reflective of countries' policy efforts regarding climate change impacts. Additionally, this approach could be indicative of which effects should be focused to further contribute in terms of policy efforts towards the sustainable development of the energy sector. This cross-country assessment encompasses a set of developed and emerging countries, with United Kingdom, Spain and Portugal representing the former and Brazil, China and India representing the latter. Energy is a focal point of many of the challenges currently faced by countries in spite of their developmental stages. This set of countries is characterised by substantially different energy mixes, socioeconomic backgrounds and commitment towards energy sustainability challenges. In fact, several authors (e.g. [14], [15]) have emphasised close interconnection between economy, energy production and use, and emission growth patterns in different countries. Therefore, in order to support the need to further address these interlinkages, it is relevant to focus on countries at different stages of development. Additionally, the relevance and adequacy of the reduction of energy consumption and related emissions have also been renewed in the context of reaching a new global climate agreement.

Cross-country data comparability has been ensured by resorting to a consistent dataset from the International Energy Agency (IEA) for energy consumption by sector (e.g. industry, transports, commercial and public services, and agriculture, forestry and fishing sector) and National Accounts Main Aggregate Database (UNStats) for economic data (e.g. country GDP and sectorial Value Added). Changes in sectorial energy consumption were assessed resorting to an

\footnotetext{
${ }^{1}$ United Nation Millennium Development Goals consist of a global alliance to achieve a total of eight goals, associated with the eradication of extreme poverty [63]. Access to energy has been considered crucial to achieve these targets [64].
} 
Index Decomposition Analysis (IDA) approach based on the multiplicative Log Mean Divisia Index (LMDI) decomposition method. This approach enabled the disaggregation of changes in energy consumption into three main drivers (activity, structure and intensity). Overall, the results obtained reflected the relevance of intensity effect regarding aggregate energy consumption, since, for all countries, main variations have been associated with both overall activity and intensity effect, in detriment of structural effect.

The remainder of the paper is organised as follows. Section 2 presents a brief overview of the literature regarding energy consumption decomposition analysis. Section 3 describes the methodological approach adopted in the present study. Section 4 presents a brief overview of the main trends regarding energy and economy nexus for the six countries included in this study, measured through changes in energy consumption and energy intensity levels. In Section 5, the results from the application of the multiplicative LMDI decomposition approach are presented, followed by a discussion of those results. Finally, Section 6 draws the main conclusions of the paper and presents avenues for future research.

\section{Literature Review}

Emergence and subsequent developments of Index Decomposition Analysis (IDA) have been interlinked and shaped (either directly or indirectly) by the energy concept. Energy related issues, namely energy efficiency and, to a certain extent, energy security, have been the primary focus of studies since the 1980s [16]. However, after 1990, with the increasing recognition of the climate change impacts, IDA has extended its scope to environmental aspects of energy production and use, particularly energy-related $\mathrm{CO}_{2}$ emissions [16], [17]. Yet, due to the primary energy's high carbon content and increasing global consumption rate, the energy sector has been considered crucial to address climate change [18]. Therefore, although IDA's initial and direct focus has shifted from energy consumption to energy-related emissions, the assessment of its drivers is still extremely relevant for policy design and evaluation. This interconnection is patent in the following literature sample (see Table 1), addressing recent studies at country level (often from a sectorial approach) and/or cross-country level (contemplating both developed and emerging countries).

Table 1 - Sample of energy and energy- related $\mathrm{CO}_{2}$ emission decomposition studies.

\begin{tabular}{|c|c|c|c|c|c|}
\hline Reference & Period & Level/Country & Sector & $\begin{array}{l}\text { Main Drivers } \\
\text { (increase) }\end{array}$ & $\begin{array}{l}\text { Main Drivers } \\
\text { (decrease) }\end{array}$ \\
\hline $\begin{array}{r}\text { Ouyang and Lyn } \\
\text { (2015) [19] }\end{array}$ & $\begin{array}{l}1991- \\
2010\end{array}$ & $\begin{array}{l}\text { National- } \\
\text { China }\end{array}$ & Industry & Activity & Energy intensity \\
\hline $\begin{array}{r}\text { Lin and Long } \\
\text { (2016) [20] }\end{array}$ & $\begin{array}{l}2005- \\
2011\end{array}$ & $\begin{array}{l}\text { National- } \\
\text { China }\end{array}$ & Industry & $\begin{array}{l}\text { Activity and } \\
\text { output/worker }\end{array}$ & $\begin{array}{l}\text { Energy Intensity and } \\
\text { structural effects }\end{array}$ \\
\hline $\begin{array}{r}\text { Zhang and Da } \\
\text { (2015) [21] }\end{array}$ & $\begin{array}{l}1996- \\
2010\end{array}$ & $\begin{array}{l}\text { National- } \\
\text { China }\end{array}$ & Industry & Activity & $\begin{array}{l}\text { Energy intensity and } \\
\text { cleaner energy mix }\end{array}$ \\
\hline $\begin{array}{r}\text { Freitas and } \\
\text { Kaneko (2011) } \\
\text { [22] }\end{array}$ & $\begin{array}{l}1970- \\
2009\end{array}$ & $\begin{array}{l}\text { National- } \\
\text { Brazil }\end{array}$ & Multi-sectorial & $\begin{array}{l}\text { Activity and population } \\
\text { growth }\end{array}$ & $\begin{array}{l}\text { Carbon intensity and } \\
\text { cleaner energy mix }\end{array}$ \\
\hline $\begin{array}{r}\text { Shaeffer et al. } \\
\text { (2009) [23] }\end{array}$ & $\begin{array}{l}1970- \\
1996\end{array}$ & $\begin{array}{l}\text { National- } \\
\text { Brazil }\end{array}$ & $\begin{array}{l}\text { Industry and } \\
\text { Residential }\end{array}$ & $\begin{array}{l}\text { Affluence; population } \\
\text { and intersectoral } \\
\text { dependencies }\end{array}$ & $\begin{array}{l}\text { Energy intensity and } \\
\text { per capita residential } \\
\text { energy use }\end{array}$ \\
\hline $\begin{array}{r}\text { Tiwari and Gulati } \\
\text { (2013) [24] }\end{array}$ & $\begin{array}{l}2001- \\
2007\end{array}$ & $\begin{array}{l}\text { National- } \\
\text { India }\end{array}$ & Transport & Transport volume & Energy intensity \\
\hline $\begin{array}{r}\text { Cansino et al. } \\
\text { (2015) [25] }\end{array}$ & $\begin{array}{l}1995- \\
2009\end{array}$ & $\begin{array}{l}\text { National- } \\
\text { Spain }\end{array}$ & Multi-sectorial & $\begin{array}{l}\text { Activity and population } \\
\text { growth }\end{array}$ & $\begin{array}{l}\text { Energy and carbon } \\
\text { intensity }\end{array}$ \\
\hline
\end{tabular}




\begin{tabular}{|c|c|c|c|c|c|}
\hline $\begin{array}{l}\text { Hammond and } \\
\text { Norman (2012) }\end{array}$ & $\begin{array}{l}1990- \\
2007\end{array}$ & $\begin{array}{l}\text { National- } \\
\text { UK }\end{array}$ & Manufacturing & Production & Energy intensity \\
\hline [26] & & & & & \\
\hline $\begin{array}{r}\text { Alves and } \\
\text { Robaina (2013) }\end{array}$ & $\begin{array}{l}1996- \\
2009\end{array}$ & $\begin{array}{l}\text { National- } \\
\text { Portugal }\end{array}$ & Industry & Activity & Energy intensity \\
\hline $\begin{array}{r}\text { Vazquez et al. } \\
\text { (2013) [28] }\end{array}$ & $\begin{array}{l}1971- \\
2012\end{array}$ & $\begin{array}{l}\text { National- } \\
\text { Cuba }\end{array}$ & Energy & $\begin{array}{l}\text { Affluence; Population } \\
\text { and Carbon intensity, }\end{array}$ & $\begin{array}{l}\text { Energy intensity of } \\
\text { production }\end{array}$ \\
\hline $\begin{array}{r}\text { Fernandez } \\
\text { Gonzalez et al. } \\
(2015)[29]\end{array}$ & $\begin{array}{l}2000- \\
2010\end{array}$ & International & Multi-sectorial & Activity & $\begin{array}{l}\text { Carbon and energy } \\
\text { intensities }\end{array}$ \\
\hline $\begin{array}{r}\text { Moutinho et al. } \\
\text { (2015) [30] }\end{array}$ & $\begin{array}{l}1995- \\
2010\end{array}$ & International & Multi-sectorial & Activity and population & Cleaner energy mix \\
\hline $\begin{array}{r}\text { Voigt et al. (2014) } \\
\text { [13] }\end{array}$ & $\begin{array}{l}1995- \\
2007\end{array}$ & International & Multi-sectorial & Structural component & Energy efficiency \\
\hline
\end{tabular}

These studies are often reflective of areas that are increasingly relevant regarding energy consumption and energy-related emissions. For instance, increases in energy consumption and energy- related $\mathrm{CO}_{2}$ emissions in the Chinese industry sector have been identified by [19] and [21]. Resorting to the LMDI method for a period between 1991 and 2010, it was possible, for both authors, to identify the activity effect as the main driver for emission increase, being offset by energy intensity and a shift towards a cleaner energy mix effects. The increase in the consumption of RES and the promotion of cogeneration were also some of the policy implications suggested by [20], in order to promote energy and carbon reductions of chemical industry in China. Additionally, based on a life-cycle assessment of wind power deployment, [11] has urged a greater introduction of this alternative in the Chinese energy mix, in order to take advantage of co-benefits regarding energy security, climate change and air pollution issues. Diversification towards a cleaner energy mix also seems to have contributed to emission reduction associated with energy consumption in Brazil from 1970 to 2009, offsetting increases driven by economic activity and population growth [22]. Actually, the relevance of the contribution of wind power projects for the Brazilian electricity mix has increased considerably, with significant socioeconomic benefits and collaboration amongst sectors as a result of local production of wind turbines [10]. Meanwhile, the main drivers for increase in the use of energy in industrial and residential sectors in Brazil, between 1970 and 1996, have been attributed to changes in affluence and population, being counterbalanced by the energy intensity effect [23]. A similar pattern seems to have happened in India. In fact, the results of a study by [31], comprising a period between 1980 and 1996, for multiple sectors of the economy, have emphasised the role of energy intensity effect in decreasing energy- related $\mathrm{CO}_{2}$ emissions offsetting the impact driven by the activity effect [31]. More recently, despite decreases in energy intensity, [24] have emphasised that energy consumption has increased in the transport sector as a result of the growth in transport volume. Although access to renewable decentralized energy sources has been recognised as crucial for improving quality of life of populations and surrounding environmental improvements, [32] and [33] have emphasised multiple barriers restricting its adoption. In spite of the efforts to reduce carbon content of power sector that continue to be developed, the Indian Government has recently implemented a National Action Plan on Climate Change (NAPCC), with several initiatives to promote the use of RES, namely solar, wind, hydro and bio-energy [9].

The main driver for energy- related $\mathrm{CO}_{2}$ emissions decrease in the UK manufacturing sector, between 1990 and 2007, has been attributed to energy intensity effect [26]. Furthermore, the forefront role played by UK regarding offshore wind deployment has been highlighted by [6], and should contribute, in a near future, to make offshore wind a significant alternative for electricity production. In the case of Spain, [25] has emphasised the role of RES as the main 
driving force for energy- related $\mathrm{CO}_{2}$ emissions reduction, for the period between 1995 and 2009. In particular, the evolution of the integration of these technologies has been assessed for La Rioja Autonomous Community (LRAC) since 1996, where a positive and significant electricity production from renewable energy technologies was expected [7]. Portugal's energyrelated $\mathrm{CO}_{2}$ emission intensity focusing on the industry sector has been decomposed, for the 1996-2009 period by [27], emphasising energy intensity as the most relevant effect. Later convergence between emission patterns of industry and energy sector has been analysed by [30], in order to determine if there has been convergence between energy and carbon intensity and what were the associated policy implications.

The relevance of carbon and energy intensity effects for Spain, Portugal and UK's $\mathrm{CO}_{2}$ emission reduction has been emphasised by [18]. However, energy intensity effect was unable to offset the activity effect as the main driver [29]. Additionally, among different groups of European countries, [34] have attributed $\mathrm{CO}_{2}$ emission reduction to a decrease in the use of fossil fuels and a shift to a cleaner energy mix. The use of RES in the European Union is expected to increase, with a significant contribution from several alternatives, among which bio-energy is considered one of the main renewable resources [8].

Finally, both developed and emerging countries have been featured in a study to determine changes in energy intensity trends of over 40 major economies, and the role of technological change in improving energy efficiency at global level was emphasised [13].

\section{Methodological Approach}

Index Decomposition Analysis (IDA) has been considered a well-established technique within energy policy scope [35][36], particularly in order to understand the causal factors regarding changes in energy consumption. It comprises Laspeyres and Divisia based methods, allowing to disaggregate energy related indicators (e.g. energy consumption and carbon emission) into its main drivers [37]. However, properties such as absence of residual terms, time reversal and aptness to cope with zero or negative values within a dataset, have contributed for the adoption of the Logarithmic Mean Divisia Index (LMDI) as the preferred method of decomposition analysis [35]. Furthermore, these characteristics have favoured this method for cross-country comparisons [38]. Energy decomposition featured in this study, results from a combination of activity, structural and intensity effects for each sector ( $i$, , following the identity function proposed by [39]:

$$
E=\sum_{i} E_{i}=\sum_{i} Q * \frac{Q i}{Q} \frac{E i}{Q i}=\sum_{i} Q S_{i} I_{i}
$$

Where $E=\sum_{i} E_{i}$ denotes the total final energy consumption in all sectors. It corresponds to the sum of the energy consumption of each sector $i$, which includes industry, transport, agriculture, and service sectors. $Q$ is the overall activity for all sectors (which would corresponds to a country's Gross Domestic Product, GDP), and $Q=\sum_{i} Q i$ represents the sum of the gross value added of each economic sector. Therefore, $\left(Q_{i} / Q\right)=S_{i}$ is given by the activity share of sector $i$ in total GDP. Meanwhile, aggregate energy intensity $(I)$ is given by the ratio between these two variables $(\mathrm{Ei} / \mathrm{Qi})$, i.e. energy consumption of sector i divided by sector i's gross value added. The ratios considered in Equation (1) express: the structural effect $\left(S_{i}\right)$ linked to changes in the sectorial activity mix of the economy; the intensity effect $\left(\mathrm{I}_{i}\right)$ related to sectorial energy intensity shifts (which can be also regarded as a result of energy efficiency measures, particularly changes in technological efficiency of energy use at the sector level); and the activity effect (Q) associated with changes in the overall level of economic activity of the country, as illustrated in Figure 1. 


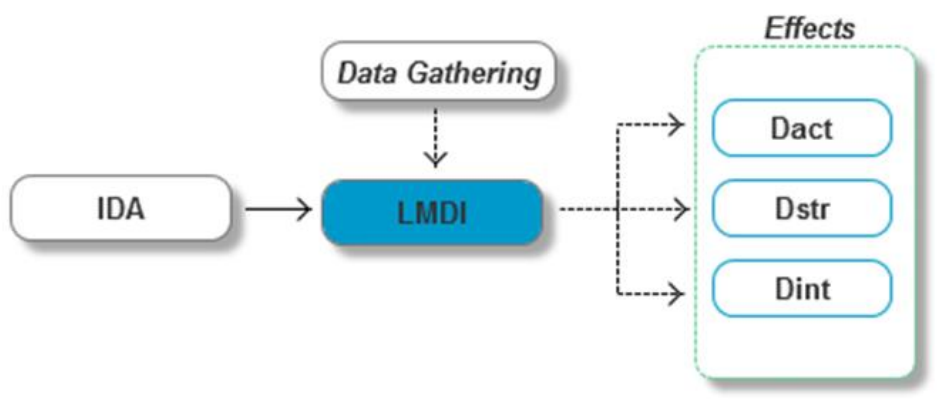

Figure 1 -Methodological Framework.

Hence, based on the multiplicative LMDI approach proposed by [39] and[40] applied to Equation (1), changes in the aggregate energy consumption (E), from year 0 to year $t$, can be computed as (Dtot):

$$
D_{t o t}=\frac{E^{t}}{E^{0}}=D_{a c t} D_{s t r} D_{i n t}
$$

where $D_{a c t}, D_{\text {str }}$ and $D_{\text {int }}$ measure the activity, structure and intensity effects, respectively, and can be calculated resorting to the following formulae [40]:

$$
\begin{aligned}
& D_{\text {act }}=\exp \left(\sum_{i} w i * \ln \left(\frac{Q^{t}}{Q^{0}}\right)\right)=\exp \left(\sum_{i} \frac{\left(E_{i}^{t}-E_{i}^{0}\right) /\left(\ln E_{i}^{t}-\ln E_{i}^{0}\right)}{\left(E^{t}-E^{0}\right) /\left(\ln E^{t}-\ln E^{0}\right)} * \ln \left(\frac{Q^{t}}{Q^{0}}\right)\right) \\
& D_{\text {str }}=\exp \left(\sum_{i} w i * \ln \left(\frac{S_{i}^{t}}{S_{i}^{0}}\right)\right)=\exp \left(\sum_{i} \frac{\left(E_{i}^{t}-E_{i}^{0}\right) /\left(\ln E_{i}^{t}-\ln E_{i}^{0}\right)}{\left(E^{t}-E^{0}\right) /\left(\ln E^{t}-\ln E^{0}\right)} * \ln \left(\frac{S_{i}^{t}}{S_{i}^{0}}\right)\right) \\
& D_{\text {int }}=\exp \left(\sum_{i} w i * \ln \left(\frac{I_{i}^{t}}{I_{i}^{0}}\right)\right)=\exp \left(\sum_{i} \frac{\left(E_{i}^{t}-E_{i}^{0}\right) /\left(\ln E_{i}^{t}-\ln E_{i}^{0}\right)}{\left(E^{t}-E^{0}\right) /\left(\ln E^{t}-\ln E^{0}\right)} * \ln \left(\frac{I_{i}^{t}}{I_{i}^{0}}\right)\right)
\end{aligned}
$$

Where $w_{i}$ represents the weight function, providing sectorial shares within overall economy, allowing to improve and simplify other existing LMDI equations (namely LMDI II), by adding to previously mentioned properties consistency in sub-sectorial aggregation [39].

With respect to the decomposition approach, other aspects should also be taken into consideration due to their potential influence in decomposition outcome, namely data availability and timespan considered for the analysis. Therefore, to perform the empirical analysis a database was built from a combination of two well established and complementary data sources: the International Energy Agency (IEA) energy balance for final energy consumption by sector and the National Accounts Main Aggregate Database (UNStats) for economic data (e.g. Gross Domestic Product (GDP) and sectorial Value Added). Since both data sources follow a common activity classification criterion - the International Standard Industrial Classification (ISIC) - data comparability amongst focused countries is ensured. For calculations, the annual chaining procedure was adopted, given consistency, multi-sectorial and long-term (1990-2012) nature of the dataset. Similarly to [13], the value for 1990 was set equal to 1 , and yearly decomposition results were then linked to each other over that period of time. By promoting comparisons of consecutive years, chained energy consumption decomposition contributes to attain a more reliable measure of changes in overall energy consumption [41]. 


\section{Energy Consumption and Energy Intensity Trends throughout 1990-2012}

In order to help better understand the results of the decomposition analysis, which will be shown in Section 5, this section presents: a) a brief overview of the main trends regarding energy and economy nexus, measured through variations in energy consumption (where energy consumption, $\mathrm{EC}$, is expressed in million tonnes of oil equivalent, Mtoe), and energy intensity, E/Q (expressed in Mtoe/2005 US constant dollars); and b) the context for these overall trends in terms of the policy measures implemented by each country through the period under analysis, with a special focus on policy measures that contemplate climate change, energy efficiency and integration of RES in the energy mix, between 1990 and 2012, based on [42]. A summary of those policy measures is presented in Annex II. With the exception of Brazil, all countries exhibit a clear declining energy intensity pattern $(\mathrm{E} / \mathrm{Q})$, while Spain and Portugal show a more moderate decrease. Energy consumption trend differs amongst each of these countries, as illustrated in Figure 2.

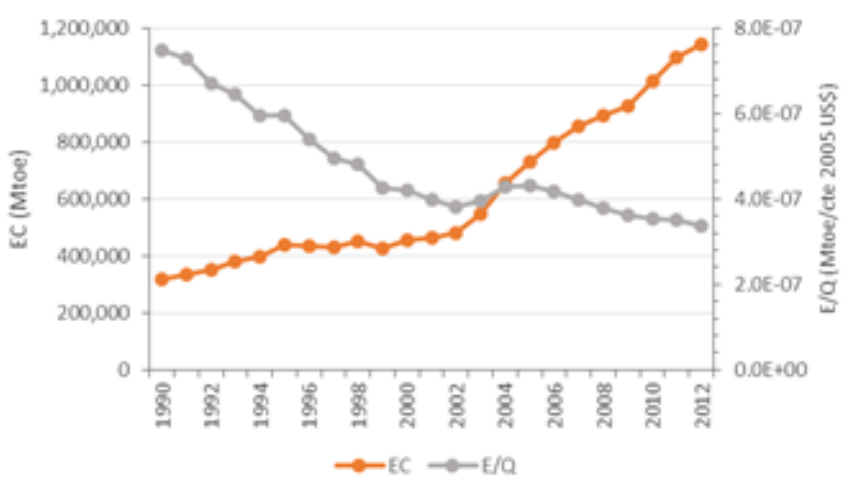

(a) China

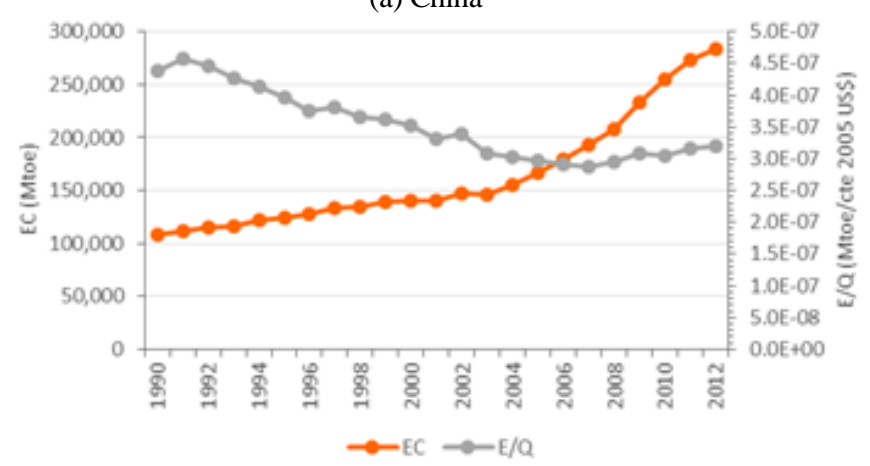

(c) India

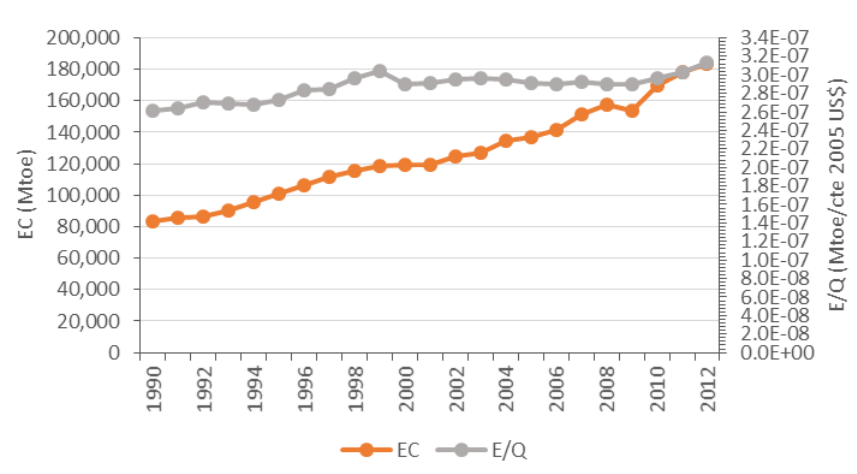

(e) Brazil

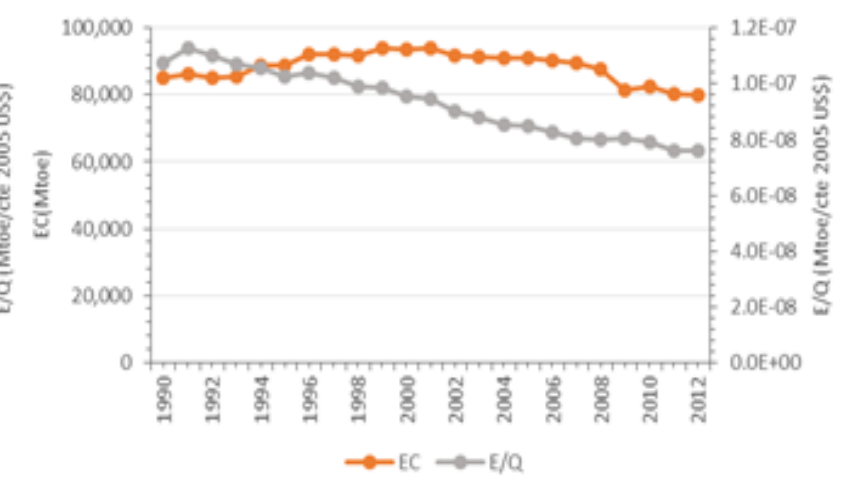

(b) UK

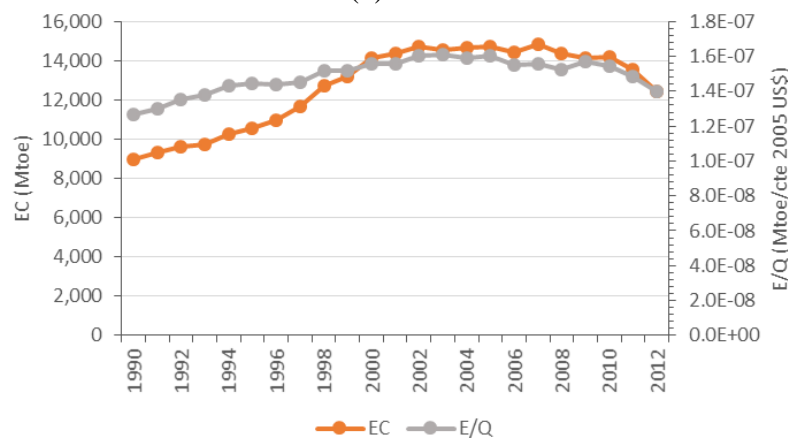

(d) Portugal

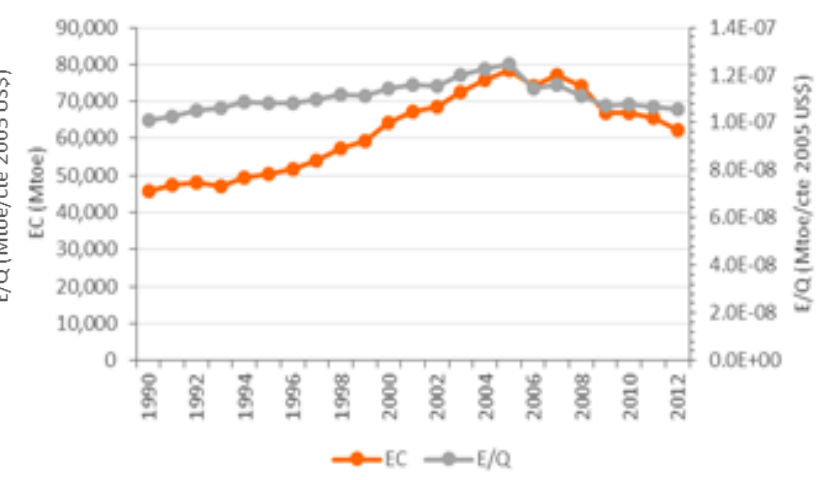

(f) Spain

Figure 2 - Cross-Country Energy intensity versus Energy consumption trend (Source: Own elaboration from data on [43], [44]). EC represents energy consumption, measured in million tonnes of oil equivalent, Mtoe, and E/Q stands for energy intensity, measured in Mtoe/2005 US constant dollars. 
As illustrated in Figure 2(a), China displayed the most accentuated drop in overall energy intensity, with a 55\% reduction between 1990 and 2012. This is in contrast with energy consumption trend (which increased $258 \%$ for the same period). Yet, that accentuated reduction is in line with the policy context for China. As can be seen on Table A7 (Annex II), China has implemented a number of policy measures focused on improving energy efficiency in several domains from the transport sector to buildings, and energy utilities.

India (see Figure 2 (c)) shares the same trend for both indicators, although in a less accentuated manner. These trends are also consistent with India's policy framework (see Table A8, Annex II), more focused on deployment of RES and climate change mitigation measures.

A similar trend regarding energy consumption has been identified in Brazil, as illustrated in Figure 2(e). Here, the increase in energy consumption, in contrast with stabilization of energy intensity, might also be a reflex of policy context. Brazil policy framework for this period shows more recent key measures for RES deployment and climate change aspects than for energy efficiency (see Table A9, Annex II). It seems that from 2003 onwards there were no new policy measures directly related to the efficient use of energy.

For the case of United Kingdom, one can see a reduction of both energy intensity and energy consumption, as illustrated in Figure 2(b).This outcome is also consistent with UK's policy framework, illustrated in Table A10, Annex II. It shows that energy efficiency measures (concerning the transport, industry, and residential sectors) have been the focus of policy decisionmakers for a larger period of time and begun also earlier than for the previous countries. Moreover, policy measures related to the incorporation of RES on the UK's energy mix and climate change mitigation measures have also been implemented.

Portugal only recently (from 2007 onwards) presented a similar decreasing tendency for energy consumption and energy intensity, as shown in Figure 2 (d). Portugal's legal framework (see Table A11, Annex II), showed that energy efficiency only recently has been focused by national policy, in comparison to other aspects and countries (namely UK). Likewise, Spain followed the same path, with simultaneous reduction of energy consumption and energy intensity after 2007, with the sharpest decrease being reached in 2009 (see Figure 2 (f)).

Thus, the assessment of these trends using the decomposition approach can further ascertain which factor is impacting energy consumption the most, evidencing also interconnectivity between activity, structural and intensity effects.

\section{Results and Discussion}

In this section, the results from the multiplicative LMDI decomposition method for the selected countries between 1990 and 2012 period are presented. Figures 3-8 show changes in total energy consumption according to variations in activity, structure and intensity effects.

In order to better identify the main driving forces underlying energy consumption, a classification criteria was adopted, similar to the one proposed by [45]. This criteria consists of three levels, that imply "no change" if variation of components (i.e., $\mathrm{D}_{\text {act }}, \mathrm{D}_{\text {int }}$, or $\mathrm{D}_{\text {str }}$ ) equals 1.00 , a negative impact contributing to increase aggregate energy consumption if it exceeds 1.00 and a positive impact contributing to decrease aggregate energy consumption (when it is below 1.00) [45]. By way of example, in their research [45] established that a value of 1 implies no change in energy consumption, a value of 1.1 means a ten per cent contribution for increasing energy consumption, and a value of 0.9 a ten per cent contribution for decrease on energy consumption.

The results shown in Figures 3-8 reflect, for all countries analysed, the relevance of intensity and activity effects regarding the explanation of changes in aggregate energy consumption, in detriment of the structure effect. Effectively, according to Figures 3-8, the contribution from this last effect is considered marginal, being the closest to "no change" level, i.e. $\mathrm{D}_{\text {str }}=1.00$. From the analysis of Figures 3-8, it can be concluded that total decomposition $\left(\mathrm{D}_{\mathrm{tot}}\right)$ closely follows either 
activity $\left(D_{\text {act }}\right)$ or intensity $\left(D_{\text {int }}\right)$ trends. Despite the contribution of these two explanatory effects, very few effects have contributed to aggregate energy consumption in a substantial way, with the exception of activity effect in China (during 1992-1995 and 2004-2007 period) and India (during 2009-2010 period). This implies that the direction of each contribution is not straightforward, requiring a country-specific insight (see tables on Annex I for aggregate energy decomposition annual time series results for each country).

\subsection{Energy consumption decomposition for emerging countries}

From 1990 to 2012, as previously mentioned, China's total energy consumption has increased significantly, which means that $\mathrm{D}_{\text {tot }}$ (the annual change in energy consumption) is always above 1 for the entire period of analysis, as illustrated in Figure 3. It is also possible to see that the growth rate of energy consumption was higher from 2002 onwards.

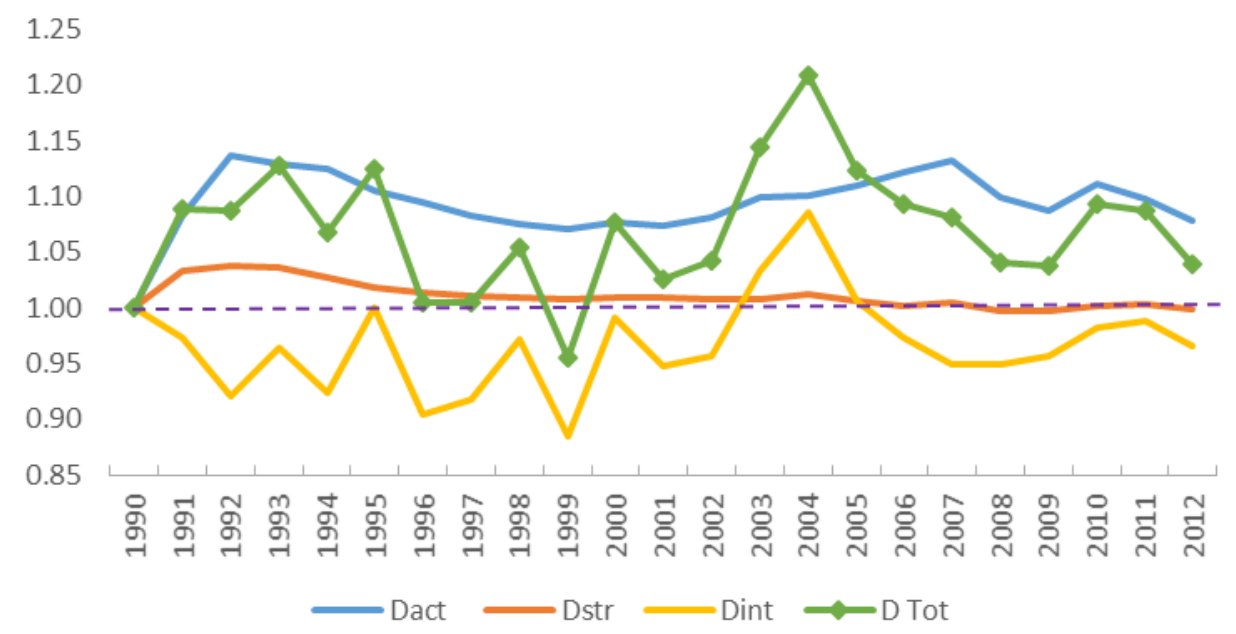

Figure 3 - Results from Multiplicative LMDI Decomposition of Aggregate Energy Consumption for China (Source: Own elaboration from data on [43], [44]).

China's energy consumption mirrors the intensity effect $\left(D_{\text {int }}\right)$, being counteracted by the activity effect $\left(\mathrm{D}_{\text {act }}\right)$. With most yearly variations bellow 1.00, contribution from the intensity effect towards the reduction of final energy consumption is clear. These results reflect a positive effort to reduce energy consumption by improving the efficient use of energy (reflected by the intensity effect) of the productive sectors of the economy (namely, the manufacturing sector). Effectively, China has adopted several policy measures (see Table A7, Annex II) promoting energy conservation in most energy intensive sectors, namely industry promoting substantial decreases in overall energy intensity [46]. Although developed to promote energy savings, it is expected that such measures potentiate other socioeconomic benefits. Health improvements and poverty alleviation have been mentioned as resulting from an improved and more efficient access to power generation [47]. Furthermore, reducing energy consumption entails a reduction of pollution emissions [41]. Despite the positive impact of the intensity effect on China's energy consumption, this has increased due to the significant economic growth of China, which is reflected on Figure 3 by the activity effect. These results are consistent with [49] assessment of energy consumption in the Chinese economy, where it was found that simultaneous increase in energy intensive activities and products for non-productive sectors have contributed for the increase in aggregate energy consumption [49]. As a consequence, although energy intensity of the economy is decreasing, energy consumption is increasing, being consistent with previous energy intensity and energy 
consumption overview trends shown in Figure 2. Meanwhile, the structural effect contributed to a moderate increase in energy consumption, particularly in the first half of the 1990s. This fact could be attributed to a change in the dominant industrial share [46].

India's total energy consumption (Dtot) change trend (Figure 4) has kept above 1.00 (Dtot>1.00) throughout the entire timeframe considered for this study (1990-2012), implying an increase in energy consumption that is in keeping with the increasing energy consumption trend previously exposed in Figure 2. A transition similar to China's, though on a different pace, has also happened in India [48].

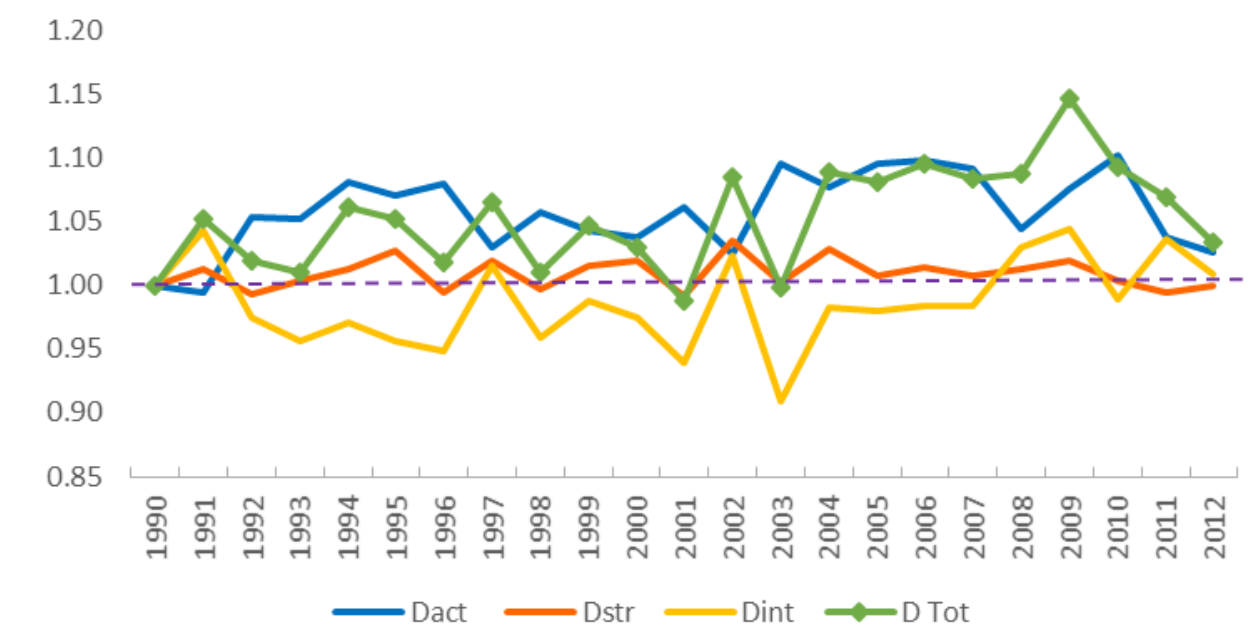

Figure 4 - Results from Multiplicative LMDI Decomposition of Aggregate Energy Consumption for India (Source: Own elaboration from data on [43], [44]).

Yet, as illustrated in Figure 4, three main periods can be identified: during the 1990 s, $D_{\text {tot }}$ is characterised by a highly fluctuating and moderately high growth of energy consumption; between 2002 and 2008 the value of $D_{\text {tot }}$ increases, reaching its peak in 2009, being followed by a decrease, though always above 1.00. This outcome is consistent with the country's economic growth path that has been the main driver of changes in energy consumption, which is reflected in the values of the activity effect $\left(D_{\text {act }}\right)$. As for the case of China, this effect was offset by the intensity effect (with few exceptions, e.g. 2008-2009 period). The New Climate Economy Report [14] has already considered 2000s decade to be the most "sustained" economic growth period experienced by India, implying also a substantial growth in energy consumption from fast economic and structural growth. However, and contrary to what happened in China, from Table A8, Annex II, there is no strong evidence that in India policy measures concerned with improving energy efficiency have been implemented. A possible alternative explanation for the reduction on India's energy intensity of the economy might be a proportionally higher increase on the value added of goods and services produced when compared with the increase in energy consumption, since energy intensity of the economy is measured as the ratio between of energy consumption and GDP. The results obtained also constitute an opportunity to address less emphasised structural issues, in order to promote aggregate improvements that are truly reflective of progress in the three main drivers of energy consumption. Though at an aggregate level, the results obtained are coherent with previous assessments by [51] that emphasised the relevance of activity effect for increasing and intensity effects for decreasing energy- related emissions at sectorial level, in the agriculture, industry and transport sectors. Despite overall decline in energy intensity, [24] adverted that economic growth towards more energy intensive alternatives is increasing energy consumption of transport and building sectors, requiring appropriate policy response. 
For Brazil, the results obtained do not evidence a clear positive correlation between intensity effect and energy consumption, as for the case of China and India (see Figure 5). With the exception of 2009 , variations in total energy consumption $\left(D_{\text {tot }}\right)$ for Brazil have kept above 1.00 , in consistency with absolute energy consumption trend, illustrated in Figure 2(e). In spite of this, fluctuations between periods of high (from 1990 to 1994 and 2002 to 2008) and moderate increase in energy consumption (e.g. from 1995 to 2001) have been reflected in changes of energy consumption ( $D_{\text {tot }}$ ), as illustrated in Figure 5.

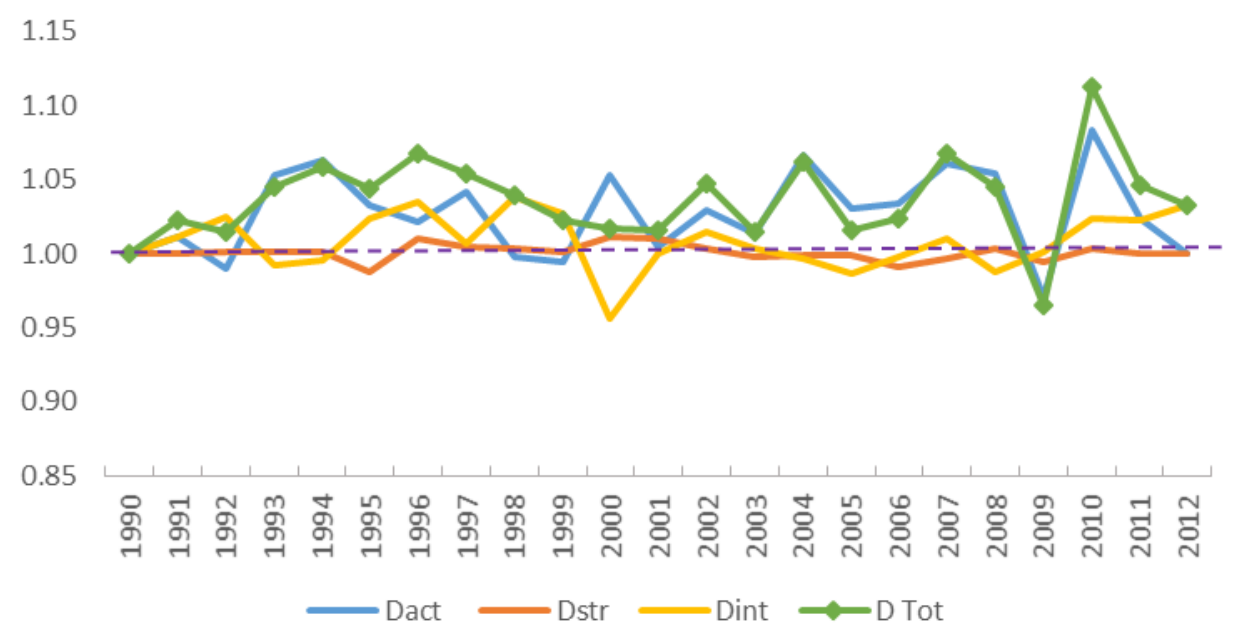

Figure 5 - Results from Multiplicative LMDI Decomposition of Aggregate Energy Consumption for Brazil (Source: Own elaboration from data on [43], [44]).

Although energy consumption follows the trend of activity effect for most of the timespan considered, this effect is not offset by the intensity effect, as happened for China and India. This might be due to the lack of implementation of policy measures related to increase energy efficiency of the country, especially from 2003 onwards as can be seen on Table A9, Annex II. This trend is in line with estimates of [54]. Similarly to China and India, the structural effect plays a much smaller role comparatively to intensity or activity effects. These results reflect, to a large extent, the socioeconomic improvements Brazil underwent in recent years, driven by activity and intensity effects [55]. However, while previous countries have also developed energy efficiency strategies to reduce energy consumption, Brazil's efforts have focused on diversifying energy mix towards less energy intensive alternatives [56], especially from 2008 onwards (Table 9, Annex II). Nonetheless, the 2009's economic crisis has also had repercussions regarding energy consumption and underlying explanatory effects. Effectively, much alike China and UK, overall energy consumption suffered an accentuated drop (8\%), resulting from an $8 \%$ decrease in the activity effect $\left(D_{\text {act }}\right)$, an $1 \%$ increase in the intensity effect $\left(D_{\text {int }}\right)$, and a decrease $(-1 \%)$ in the structural effect $\left(D_{\text {str }}\right)$, respectively. However, considering the six countries analysed in this study, Brazil presents one of the lowest energy intensity trends [57]. Therefore, both decomposition and growth rate trends suggest that attention should be brought to intensity effect with special emphasis on transport and service sector, regarding energy consumption and intensity improvements.

\subsection{Energy consumption decomposition for developed countries}

Between 1990 and 2012, UK's energy consumption trend could be divided in two different phases. Prior to year 2000, though with fluctuations, energy consumption presented an increasing trend, since $D_{\text {tot }}$ value is always above 1 , as illustrated in Figure 6. After 2002, the value of $D_{\text {tot }}$ is always below or equal 1, which has led to a decrease of energy consumption until 2012. 


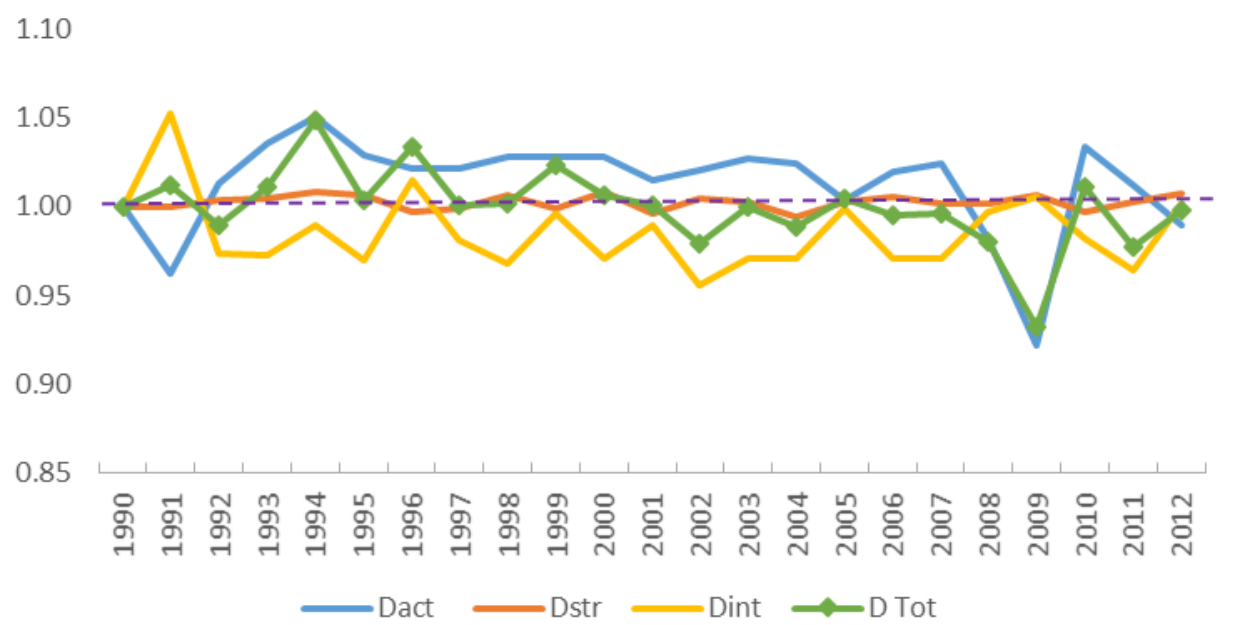

Figure 6 - Results from Multiplicative LMDI Decomposition of Aggregate Energy Consumption for United Kingdom (Source: Own elaboration from data on [43], [44]).

From Figure 6, it is clear that the main driver for the behaviour of energy consumption has been the activity effect, reflecting the growth of the UK economy. As was the case of China and India, the intensity effect has contributed for compensating the increase in energy consumption. This reflects the adoption of policy measures related to the improvement of energy efficiency of the UK economy and climate change mitigation measures, as evidenced on Table A10 of Annex II.

Once more, the results obtained have shown a strong correlation between energy consumption, the intensity effect and economic activity. Conversely to China, however, these results suggest that UK was able to attain resource decoupling, which is in line with [13] outcome for UK's energy intensity decomposition. The results obtained suggest that policy efforts in reducing energy consumption via intensity effect have been effective. Furthermore, measures contained in 2020 Strategy feature to a great extent energy savings through improvements in efficiency (20\%), which are related to the intensity effect [29]. Notwithstanding, the results obtained diverge from the findings of [29]. This divergence, however, could be associated with the fact that the study undertaken in this paper resorts to an aggregate database, hindering the assessment of structural changes, affecting assessment of energy consumption drivers through decomposition approach. In fact, it should be noticed that when dealing with aggregate data part of the structural effect is being captured by the intensity effect. Thus, the result that the intensity effect has been the more relevant should be relativized, since there is a structural effect embedded in the intensity effect generated by changes in the composition of the productive sectors of the economy.

Similarly to UK, Portugal's changes in energy consumption trend present two main phases between 1990 and 2012. From 1990 to 2002, has seen an increase in energy consumption, reflected by variation of energy consumption $\left(\mathrm{D}_{\mathrm{tot}}\right)$ above 1.00, as illustrated in Figure 7. After 2002, the value of $D_{\text {tot }}$ is below 1 , which has led to a decrease in country's energy consumption, though always with fluctuations. 


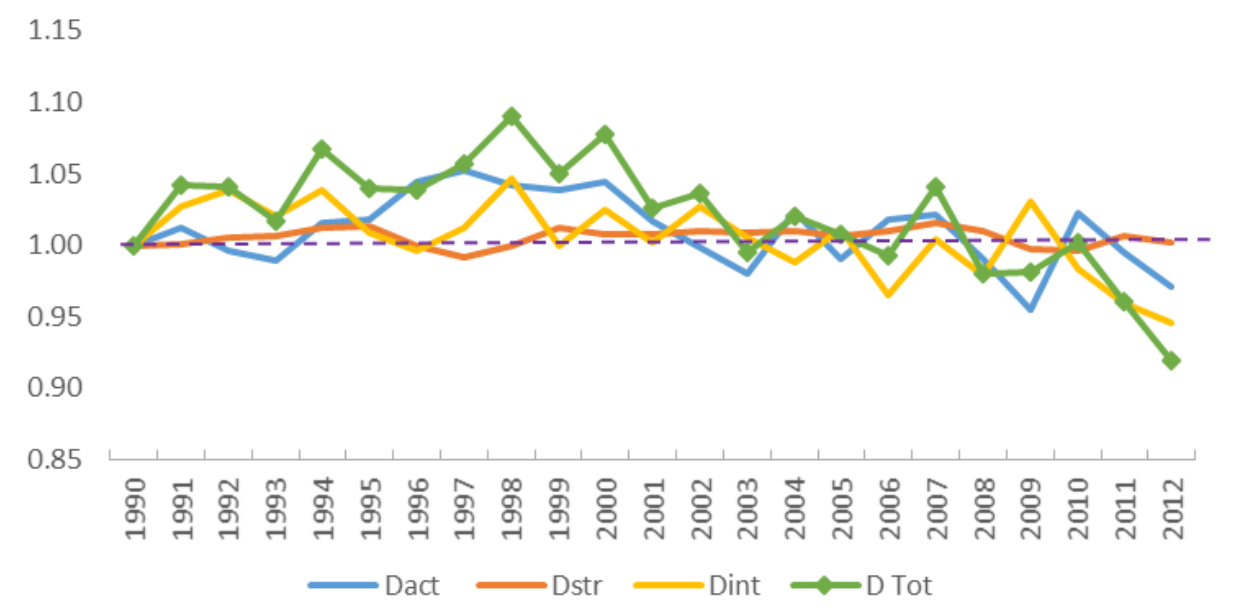

Figure 7 - Results from Multiplicative LMDI Decomposition of Aggregate Energy Consumption for Portugal (Source: Own elaboration from data on [43], [44]).

Portugal's aggregate energy consumption reflects the influence of two main drivers: activity and intensity effects. They counteract or align each other over the analysed period of time, being offset by the structure effect. For instance, for the 1992 to 1993 period when the activity effect contributes to a decrease in energy consumption (due to an economic recession), both intensity and structure effects tend to increase aggregate energy consumption. Therefore, an increase in overall energy consumption is observed. This trend is reversed during the 1997-1998 period, with both activity and intensity effect increasing energy consumption, while the structure effect contributes in the opposite direction, i.e. decreasing energy consumption. In 2009, energy intensity decreases following the activity effect, being coincident with socioeconomic crisis that had begun in the previous year. In fact, although from 2008 to 2009 energy consumption in Portugal remained relatively stable, the three components that explain the change in energy consumption show a different path: energy consumption declines due to the activity and structure effects but increases due to the intensity effect. From this period onwards, there has been a pronounced decrease of intensity and activity effects, which is very likely related to the recession the country experienced in those years. The results obtained are in line with the estimates of [59], according to which recession and "weak economic growth" have contributed to a decrease in energy consumption and intensity. However, [59] also claim that there has been a substantial transition into the service sector, although reductions in energy consumption have been mainly attributed to improvements in energy intensity. These improvements might be related to policy measures implemented to increase energy efficiency in Portugal. Some examples are the Plan for Promoting Energy Efficiency in Electricity Consumption, the Management System of Intensive Energy Consumption, and the Energy Efficiency and Endogenous Energies (E4) Programme (Table A11, Annex II).

As illustrated in Figure 8, changes in energy consumption trend for Spain converges with that of UK and Portugal, being divided into two main opposing phases. Before the year 2005, energy consumption presented an increasing trend, reflected by a $\mathrm{D}_{\text {tot }}$ above 1.00 . Afterwards, $\mathrm{D}_{\text {tot }}$ is below 1.00 , mirroring an absolute energy consumption trend decrease, though with fluctuations. 


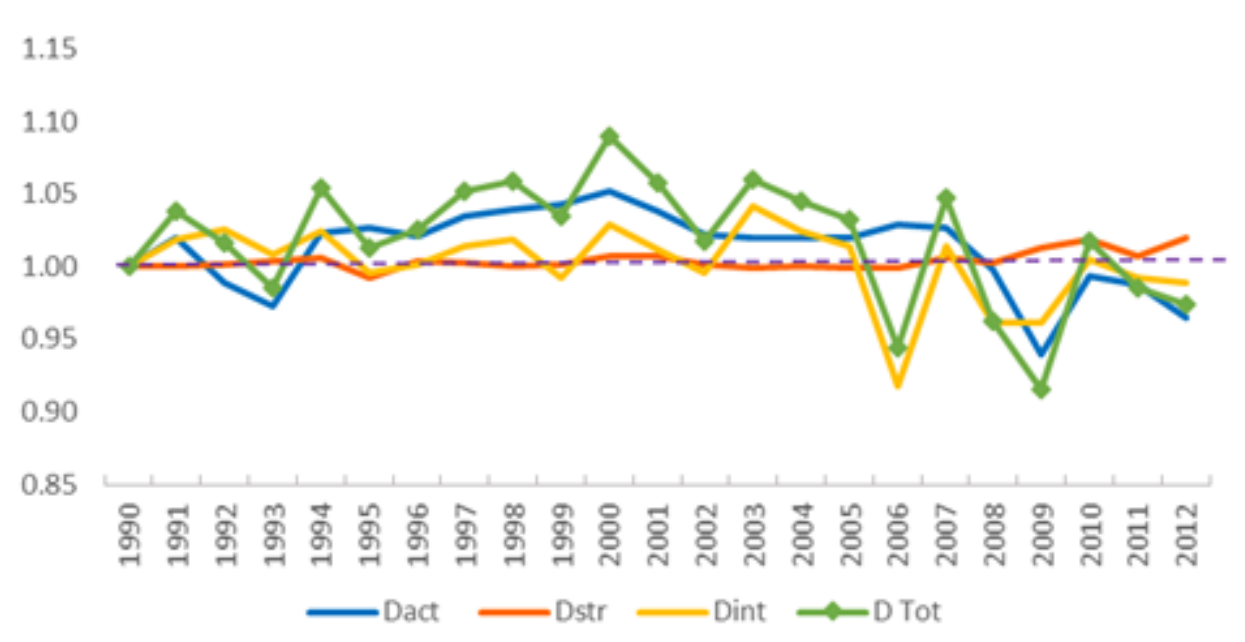

Figure 8 - Results from Multiplicative LMDI Decomposition of Aggregate Energy Consumption for Spain (Source: Own elaboration from data on [43], [44]).

Until 2004 energy intensity effect contributed along with the activity effect towards the increase in total energy consumption, and only recently (since 2006) this trend has shifted, from driver to restraining effect for energy consumption growth. This might be explained by the fact that, especially from 2005 onwards, several policy measures and instruments started to be implemented in order to address the issue of improving efficiency in energy consumption and use, such as, for example, the Implementation of the Energy Performance in Buildings Directive, the Efficient Vehicle Incentives Programme, or the Energy Efficiency Action Plan (see Table A12, Annex II). The results obtained are consistent with the assessments of [58] and [25], that emphasised the increasing role played by technological improvements and enforcement of energy efficiency policies. During the 2008-2010 time period, the results obtained also showed that overall energy reduction has benefited more from a decline in activity effect rather than an improvement in the energy intensity effect. Activity reduction resulting from juxtaposition with economic crisis has contributed to deteriorate the intensity effect by forcing equipment to work below its "optimum yield rate" [58] and by slowing down investment in new and more efficient technologies [18], [25]. Additionally, [25] have also highlighted that the energy intensity effect has had a crucial role in improving energy consumption of the power sector. Transformation of primary energy into energy services requires substantial amounts of electricity [25], which can be reduced through intensity effect by promoting efficiency and alternative (less energy and carbon intensive) technological choices. This perspective stresses the need to consider all aspects related to energy consumption, within the intensity effect ${ }^{2}$, in order to support effective energy reduction that promotes improvements in other energy-related policy objectives such as climate change, energy security and air pollution.

\subsection{Discussion of results}

Overall, and regardless of the group of countries analysed (emerging or developed), the decomposition results obtained have emphasised the relevance of activity $\left(\mathrm{D}_{\text {act }}\right)$ and intensity $\left(\mathrm{D}_{\text {int }}\right)$ effects as the main drivers for aggregate energy consumption. This approach has also underscored the need to address the less prominent structural effect $\left(D_{\text {str }}\right)$ in order to promote improvements reflective of all "explanatory" effects. Table 2 presents a summary of the impact of each effect on energy consumption changes for the six countries analysed.

\footnotetext{
${ }^{2}$ Intensity effect should encompass all aspects related to energy consumption, from "energy conservation and energy saving investments; structure and efficiency; technological choices"; in addition to behavioural aspects [18].
} 
Table 2 - Summary of decomposition results of energy consumption change by country.

\begin{tabular}{l|cccccc} 
Decomposition Effects & China & India & Brazil & $\begin{array}{l}\text { United } \\
\text { Kingdom }\end{array}$ & Portugal & Spain \\
\hline Total Effect (Dtot) & $\nearrow$ & $\nearrow$ & $\nearrow$ & $\searrow$ & $\nearrow$ & $\nearrow$ \\
Intensity Effect (Dint) & $\searrow$ & $\searrow$ & $\nearrow$ & $\searrow$ & $\searrow$ & $\searrow$ \\
Activity Effect (Dact) & $\nearrow$ & $\nearrow$ & $\nearrow$ & $\nearrow$ & $\nearrow$ & $\nearrow$ \\
Structural Effect (Dstr) & $\leftrightarrow$ & $\leftrightarrow$ & $\leftrightarrow$ & $\leftrightarrow$ & $\leftrightarrow$ \\
\hline $\begin{array}{l}\text { Note: } \text { The arrows indicate the contribution of each driving force for changes in energy consumption }(\nearrow \text { Increase; } \downarrow \text { decrease; } \\
\leftrightarrow \text { marginal). }\end{array}$
\end{tabular}

The results obtained require, nonetheless, a careful interpretation given the aggregate nature of the database used in the current study. This inhibits properly accounting for shifts at structural level, leading to overlap and possible misinterpretation between structure and intensity effects [61]. This shortcoming should be taken into account given the fact that decomposition approach has been a widely used tool in energy planning decision-making, potentially avoiding development of misconceived policies [62]. In fact, the results of the decomposition approach are influenced by the composition and evolution of each country activity (or sectorial) mix. Table 3 shows energy consumption (EC) and energy intensity (E/Q) growth rates per country and sector. For instance, if more energy intensive sectors tend to prevail, there will be more energy requirements leading to its increase overtime, and vice-versa. This emphasises the need to ascertain which economic sectors are more energy intensive [41].

Table 3 - Energy consumption (EC) and Energy Intensity (E/Q) growth rates per country and sector.

\begin{tabular}{c|l|llllll}
\multicolumn{2}{l}{ Growth Rates* } & China & India & Brazil & UK & Portugal & Spain \\
\hline \multirow{3}{*}{} & Industry & $232 \%$ & $143 \%$ & $108 \%$ & $-25 \%$ & $2 \%$ & $5 \%$ \\
& Transport & $603 \%$ & $250 \%$ & $140 \%$ & $-1 \%$ & $69 \%$ & $39 \%$ \\
\cline { 2 - 7 } & Services & $402 \%$ & $97 \%$ & $145 \%$ & $25 \%$ & $202 \%$ & $194 \%$ \\
& Agriculture & $18 \%$ & $166 \%$ & $72 \%$ & $-33 \%$ & $-10 \%$ & $62 \%$ \\
\hline \multirow{4}{*}{} & Industry & $-58 \%$ & $-38 \%$ & $13 \%$ & $-43 \%$ & $-19 \%$ & $-7 \%$ \\
& Transport & $-11 \%$ & $-56 \%$ & $31 \%$ & $-25 \%$ & $35 \%$ & $-18 \%$ \\
\cline { 2 - 7 } & Services & $-37 \%$ & $-64 \%$ & $34 \%$ & $-5 \%$ & $140 \%$ & $102 \%$ \\
\cline { 2 - 7 } & Agriculture & $-85 \%$ & $45 \%$ & $-6 \%$ & $-49 \%$ & $-29 \%$ & $36 \%$ \\
\hline *comparatively to 1990 values & & & & & \\
\hline
\end{tabular}

As can be seen on Table 3, China's decreasing energy intensity trend can be explained by an accentuated decrease $(-58 \%)$ of industry's energy intensity, and to a lower extent a decrease (11\%) of transport's energy intensity. Similarly, [21] have estimated that, during 1996-2010 period, secondary industry registered the highest decrease of energy intensity rate $(44,08 \%)$ followed by tertiary industry $(37,43 \%)$. Growth rates exposed in Table 3 also emphasise a sharp decrease in agriculture sector's energy intensity (less 85\%) being indicative of the transition China experienced from an agricultural based economy to an industrial based economy [48]. India has experienced a similar pattern regarding energy consumption and energy intensity trends for the four sectors shown on Table 3. In the case of Brazil, the increase of both indicators resulted from an increase in all sectors (except agricultural sector for energy intensity), two of which highly energy intensive (industry $13 \%$ and transport $31 \%$ ) in addition to service sector (34\%). [23] have emphasised this shift in Brazilian activity and use of energy context, denoting industry's sector increase in contrast to stagnancy of residential sector.

Simultaneous decrease of energy consumption and energy intensity in the UK, reflect accentuated decrease of energy intensive sectors such as industry (- 43\%) and transports (-25\%) in contrast to less energy intensive sectors such as commercial and service sector. These trends are consistent 
with [52]'s results that stressed the reduction of the weight of energy intensive industries on UK's economy and a shift towards service sector. Reductions extended to all sectors have also been reported by [52], which might be associated with policy measures undertaken for each sector (as can be seen on Table 10, Annex II).

Decomposition results are in line with sectorial growth rates for Portugal that have emphasised reductions of energy intensity in sectors such as industry and agriculture in contrast with energy intensity increases in service and transport sectors. Comparing 1990 to 2012, Portugal has registered an accentuated increase in the weight of less energy intensive sectors. While industry's energy intensity decreased $19 \%$, commercial and service sector increase far exceeded the increase in the transport sector (35\%). These growth rates are aligned with sectorial contribution to overall economy suggested by [60], emphasising for both indicators an increasing relevance of service and transport sectors in contrast to a declining agricultural sector. Relevance of service sector's energy intensity growth $(102 \%)$ has also been registered for Spain in contrast to decreases in energy intensity verified in the industry (less 7\%) and transport sectors (less 18\%). Higher growth rates for tertiary sector versus lower growth rates for industry and transport sectors have also been emphasised by [60].

An overview of policy measures scope for the countries analysed in the current study, presented in Tables A7-A12 (Annex II), allows one to better understand the role of each driver of energy consumption. As above-mentioned, besides the activity effect, energy intensity effect is an important driver of changes in energy consumption for all countries and, particularly, for China, India and UK. This result coincides with the implementation of important policy measures and instruments in those countries regarding the improvement of energy efficiency that can have a significant impact on energy consumption and contribute to curb emissions. Examples are the Long-term Plan of Energy Conservation, the Plan for Promotion of Energy Efficient Products, and the National Building Energy Standard, in the case of China, or the Community Energy Savings Programme, the Carbon Reduction Commitment Energy Efficiency Scheme, and the Energy Act in the case of UK (Tables A7 to A10, Annex II, respectively).

Besides the design of policy measures focused on improving the energy intensity of a country, it should also be recognised the importance of the structural effects, given the increasing relevance of service and transport sectors for overall energy consumption. In this respect, the six countries, in general, have been implementing policy measures and regulatory instruments to address energy consumption on the transport and residential sectors. For example, in the case of the transport sector, there are the Vehicle Fuel Economy Standards, and the Energy Saving and New Energy Automotive Industry Development Plan 2012-2020, in China, the New Deal for Transport, in UK, and the Efficient Vehicle Incentives Programme, in Spain (Tables A7, A10 and A12, Annex II, respectively). For the residential sector, examples are the Energy Conservation Building Code, in India, the Energy Efficiency Program in Public Buildings, in Brazil, and the National System for Energy and Indoor Air Quality Certification of Buildings, in Portugal (Tables A8, A9 and A11, Annex II, respectively)).

Finally, increasing incorporation of renewable energy sources and natural gas on the country's energy mix as well as greater technical efficiency (Tables A7-A12, Annex II) has contributed to achieve a sustainable development of the energy sector, while contributing, at the same time, to reduce both external energy dependence (thus promoting energy security) and GHG emissions [60]. 


\section{Conclusion}

Although a cornerstone for development, past and current energy uses have often posed a major challenge for policy makers regarding energy planning and management. The use of tools, such as the decomposition approach, can contribute to improve energy related decision-making by identifying and exposing the main driving forces underlying different energy consumption growth paths [41]. Resorting to the Logarithmic Mean Divisia Index (LMDI) method, as proposed by [39], aggregate energy consumption was decomposed into three main explanatory effects: activity effect $\left(D_{\text {act }}\right)$, structural effect $\left(D_{\text {str }}\right)$ and intensity effect $\left(D_{\text {int }}\right)$. Hence, assessment of energy consumption trends, through the decomposition approach, provides critical information. In particular, regarding which is the dominant factor that should be focused during policy design, in order to improve overall energy consumption.

The results obtained seem to indicate the prevalence of the intensity and activity effects in explaining changes in aggregate energy consumption. For all the countries analysed, the main variations have been associated with those two effects over the structural effect. Notwithstanding, the direction of each contribution is not straightforward, requiring a country-specific insight. As expected, energy consumption presented an increasing trend in emerging countries (Brazil, China and India), contrasting with a decreasing trend in developed countries (UK, Portugal and Spain). Nevertheless, for China, UK and India, the intensity effect clearly contributed to a decrease in aggregate energy intensity, reflecting and reinforcing the relevance that energy efficiency has gained within the energy policy scope. However, these efforts have often been offset by the activity effect, clearly contributing to an increase in overall energy consumption. This reflects the need to adopt a more holistic perspective to promote energy conservation, namely addressing effects that had a marginal contribution towards energy conservation improvements (structural effect).

Meanwhile, although influenced by these effects, contribution of the intensity effect to improve overall energy consumption is not as straightforward for Brazil, Portugal and Spain. Notwithstanding, and contrary to Brazil, Portugal and Spain present a decreasing energy consumption trend that coincided with the 2007-2009 period. This period corresponds to an economic recession, and has affected all countries without exception, clearly influencing the activity and intensity contribution to overall energy consumption. Therefore, improvements in the intensity effect resulted from a combination of policies focusing on energy efficiency and economic recession. Although affected by this, Brazil's energy consumption and intensity has grown, requiring measures at the energy intensity level to improve energy conservation. Hence, based on the main drivers, decomposition approach can contribute to develop a strategic approach appropriate for each country. Furthermore, by taking into consideration all factors influencing energy consumption, developed policies can benefit other energy priorities, such as environmental concerns.

Nevertheless, further studies, resorting to a more disaggregate approach could provide more indepth development of appropriated policies. However, in order to promote a cross-country comparison, a more detailed, universal access database would be required.

\section{Acknowledgements}

This research was supported by a Marie Curie International Research Staff Exchange Scheme Fellowship within the $7^{\text {th }}$ European Union Framework Programme, under project NETEPEuropean Brazilian Network on Energy Planning (PIRSES-GA-2013-612263). Support from CNPq is also acknowledged, as well as the support of ALGORITMI, a research Centre at the University of Minho. This work has been supported by COMPETE: POCI-01-0145-FEDER007043 and FCT - Fundação para a Ciência e Tecnologia within the Project Scope: UID/CEC/00319/2013. 


\section{References}

[1] M. Hirschnitz-Garbers, A. Tan, A. Gradmann, and T. Srebotnjak, "Key drivers for unsustainable resource use - categories, effects and policy pointers," J. Clean. Prod., vol. 2, no. August 2011, 2015.

[2] S. Gupta, "Decoupling : a step toward sustainable development with reference to OECD countries," vol. 4509, no. November, 2015.

[3] L. van O. Ester van der Voet, S. B. Stephan Moll, Helmut Schütz, and G. W. Sander de Bruyn, Maartje Sevenster, "Policy review on decoupling : Development of indicators to assess decoupling of economic development and environmental pressure in the EU-25 and AC-3 countries," 2005.

[4] F. Creutzig, J. C. Goldschmidt, P. Lehmann, E. Schmid, F. von Blücher, C. Breyer, B. Fernandez, M. Jakob, B. Knopf, S. Lohrey, T. Susca, and K. Wiegandt, "Catching two European birds with one renewable stone: Mitigating climate change and Eurozone crisis by an energy transition," Renew. Sustain. Energy Rev., vol. 38, pp. 1015-1028, 2014.

[5] A. M. Foley, B. P. Ó Gallachóir, E. J. McKeogh, D. Milborrow, and P. G. Leahy, “Addressing the technical and market challenges to high wind power integration in Ireland," Renew. Sustain. Energy Rev., vol. 19, pp. 692-703, 2013.

[6] P. Higgins and A. Foley, "The evolution of offshore wind power in the united kingdom," Renew. Sustain. Energy Rev., vol. 37, pp. 599-612, 2014.

[7] L. M. López González, J. M. Sala Lizarraga, J. L. Míguez Tabarés, and L. M. López Ochoa, "Contribution of renewable energy sources to electricity production in the La Rioja Autonomous Community, Spain. A review," Renew. Sustain. Energy Rev., vol. 11, no. 6, pp. 1244-1259, 2007.

[8] N. Scarlat, J.-F. Dallemand, F. Monforti-Ferrario, M. Banja, and V. Motola, "Renewable energy policy framework and bioenergy contribution in the European Union - An overview from National Renewable Energy Action Plans and Progress Reports," Renew. Sustain. Energy Rev., vol. 51, pp. 969-985, 2015.

[9] S. S. Chandel, R. Shrivastva, V. Sharma, and P. Ramasamy, "Overview of the initiatives in renewable energy sector under the national action plan on climate change in India," Renew. Sustain. Energy Rev., vol. 54, pp. 866-873, 2016.

[10] A. A. Juárez, A. M. Araújo, J. S. Rohatgi, and O. D. Q. De Oliveira Filho, "Development of the wind power in Brazil: Political, social and technical issues," Renew. Sustain. Energy Rev., vol. 39, pp. 828834, 2014.

[11] B. Xue, Z. Ma, Y. Geng, P. Heck, W. Ren, M. Tobias, A. Maas, P. Jiang, J. A. Puppim de Oliveira, and T. Fujita, "A life cycle co-benefits assessment of wind power in China," Renew. Sustain. Energy Rev., vol. 41, no. 72, pp. 338-346, 2015.

[12] A. Murata, J. Liang, R. Eto, K. Tokimatsu, K. Okajima, and Y. Uchiyama, "Environmental co-benefits of the promotion of renewable power generation in $\{$ China $\}$ and $\{$ India $\}$ through clean development mechanisms," Renew. Energy, vol. 87, Part 1, pp. 120-129, 2016.

[13] S. Voigt, E. De Cian, M. Schymura, and E. Verdolini, "Energy intensity developments in 40 major economies: Structural change or technology improvement?," Elsevier B.V., 2014.

[14] The Global Comission on the Economy and Climate, "New Climate Economy c/o World Resources Institute," Washington, 2014.

[15] C. Yao, K. Feng, and K. Hubacek, "Ecological Informatics Driving forces of CO 2 emissions in the G20 countries : An index decomposition analysis from 1971 to 2010," Ecol. Inform., vol. 26, pp. 93-100, 2015.

[16] X. Y. Xu and B. W. Ang, "Index decomposition analysis applied to CO 2 emission studies," Ecol. Econ., vol. 93, pp. 313-329, 2013.

[17] B. W. Ang and F. Q. Zhang, "A survey of index decomposition analysis in energy and environmental studies,” Energy, vol. 25, no. 12, pp. 1149-1176, Dec. 2000.

[18] P. Fernández González, M. J. Presno, and M. Landajo, "Regional and sectoral attribution to percentage changes in the European Divisia carbonization index," Renew. Sustain. Energy Rev., vol. 52, pp. 1437$1452,2015$.

[19] X. Ouyang and B. Lin, "An analysis of the driving forces of energy-related carbon dioxide emissions in China's industrial sector," Renew. Sustain. Energy Rev., vol. 45, pp. 838-849, 2015.

[20] B. Lin and H. Long, "Emissions reduction in China's chemical industry - Based on LMDI," Renew. Sustain. Energy Rev., vol. 53, pp. 1348-1355, 2016.

[21] Y.-J. Zhang and Y.-B. Da, "The decomposition of energy-related carbon emission and its decoupling with economic growth in China," Renew. Sustain. Energy Rev., vol. 41, pp. 1255-1266, 2015.

[22] L. Charlita, D. Freitas, and S. Kaneko, "Decomposition of CO 2 emissions change from energy consumption in Brazil : Challenges and policy implications," Energy Policy, vol. 39, no. 3, pp. 1495$1504,2011$.

[23] U. Wachsmann, R. Wood, M. Lenzen, and R. Schaeffer, "Structural decomposition of energy use in Brazil from 1970 to 1996," Appl. Energy, vol. 86, no. 4, pp. 578-587, 2009. 
[24] P. Tiwari and M. Gulati, "An analysis of trends in passenger and freight transport energy consumption in India,” Res. Transp. Econ., vol. 38, no. 1, pp. 84-90, 2013.

[25] J. M. Cansino, A. Sánchez-braza, and M. L. Rodríguez-arévalo, "Driving forces of Spain ’ s CO 2 emissions : A LMDI decomposition approach,” Renew. Sustain. Energy Rev., vol. 48, pp. 749-759, 2015.

[26] G. P. Hammond and J. B. Norman, "Decomposition analysis of energy-related carbon emissions from UK manufacturing," Energy, vol. 41, no. 1, pp. 220-227, 2012.

[27] M. Robaina Alves and V. Moutinho, "Decomposition analysis and Innovative Accounting Approach for energy-related CO2 (carbon dioxide) emissions intensity over 1996-2009 in Portugal,” Energy, vol. 57, pp. 775-787, 2013.

[28] L. Vazquez, J. Luukkanen, H. Kaisti, M. Käkönen, and Y. Majanne, "Decomposition analysis of Cuban energy production and use: Analysis of energy transformation for sustainability,” Renew. Sustain. Energy Rev., vol. 49, pp. 638-645, 2015.

[29] P. Fernández González, M. Landajo, and M. J. Presno, "Multilevel LMDI decomposition of changes in aggregate energy consumption. A cross country analysis in the EU-27," Energy Policy, vol. 68, pp. 576584, 2014.

[30] V. Moutinho, M. Robaina-Alves, and J. Mota, "Carbon dioxide emissions intensity of Portuguese industry and energy sectors: A convergence analysis and econometric approach," Renew. Sustain. Energy Rev., vol. 40, pp. 438-449, 2014.

[31] S. Paul and R. N. Bhattacharya, "CO2 emission from energy use in India: a decomposition analysis," Energy Policy, vol. 32, no. 5, pp. 585-593, 2004.

[32] S. Luthra, S. Kumar, D. Garg, and A. Haleem, "Barriers to renewable/sustainable energy technologies adoption: Indian perspective," Renew. Sustain. Energy Rev., vol. 41, pp. 762-776, 2015.

[33] A. Chauhan and R. P. Saini, "Renewable energy based off-grid rural electrification in Uttarakhand state of India: Technology options, modelling method, barriers and recommendations," Renew. Sustain. Energy Rev., vol. 51, pp. 662-681, 2015.

[34] V. Moutinho, A. C. Moreira, and P. M. Silva, "The driving forces of change in energy-related CO2 emissions in Eastern, Western, Northern and Southern Europe: The LMDI approach to decomposition analysis," Renew. Sustain. Energy Rev., vol. 50, pp. 1485-1499, 2015.

[35] B. . Ang, "Decomposition analysis for policymaking in energy:," Energy Policy, vol. 32, no. 9, pp. 1131-1139, Jun. 2004.

[36] C. Wang, "Changing energy intensity of economies in the world and its decomposition," Energy Econ., vol. 40, pp. 637-644, Nov. 2013.

[37] T. a. B. Smit, J. Hu, and R. Harmsen, "Unravelling projected energy savings in 2020 of EU Member States using decomposition analyses," Energy Policy, vol. 74, pp. 271-285, 2014.

[38] G. S. Mishra, S. Zakerinia, S. Yeh, J. Teter, and G. Morrison, "Mitigating climate change: Decomposing the relative roles of energy conservation, technological change, and structural shift," Energy Econ., vol. 44, pp. 448-455, 2014.

[39] B. W. Ang, “The LMDI approach to decomposition analysis: A practical guide," Energy Policy, vol. 33, no. 7, pp. 867-871, 2005.

[40] B. W. Ang and F. L. Liu, "A New Energy Decomposition Method: Perfect in Decomposition and Consistant in Aggregation," Energy, vol. 26, pp. 537-548, 2001.

[41] A. Baležentis, T. Baležentis, and D. Streimikiene, "The energy intensity in Lithuania during 1995-2009: A LMDI approach,” Energy Policy, vol. 39, no. 11, pp. 7322-7334, 2011.

[42] International Energy Agency (IEA), "Policies and Measures Database," 2016. [Online]. Available: http://www.iea.org/policiesandmeasures/.

[43] International Energy Agency, “International Energy Agency Statistics,” Energy Statistics, 2015. [Online]. Available: https://www.iea.org/statistics/statisticssearch/.

[44] United Nations Statistics Division, "National Accounts Main Aggregates Database," 2014. [Online]. Available: http://unstats.un.org/unsd/snaama/cList.asp.

[45] S. T. Henriques and A. Kander, "The modest environmental relief resulting from the transition to a service economy," Ecol. Econ., vol. 70, no. 2, pp. 271-282, 2010.

[46] W. Wang, X. Liu, M. Zhang, and X. Song, "Using a new generalized LMDI (logarithmic mean Divisia index) method to analyze China's energy consumption," Energy, vol. 67, pp. 617-622, 2014.

[47] L. Ryan and N. Campbell, "Spreading the net: The Multiple benefits fo Energy Efficiency Improvements," p. 37, 2012.

[48] Zmarak Shalizi, "Energy and Emissions: Local and Global Effects of the Rise of China and India," Research Working Paper 4209, 2007.

[49] H. Nie and R. Kemp, "Why did energy intensity fluctuate during 2000-2009?. A combination of index decomposition analysis and structural decomposition analysis," Energy Sustain. Dev., vol. 17, no. 5, pp. 
482-488, 2013.

[50] F. Li, Z. Song, and W. Liu, "China's energy consumption under the global economic crisis: Decomposition and sectoral analysis," Energy Policy, vol. 64, pp. 193-202, Jan. 2014.

[51] H. R. S. Uğural, "Sectoral Decomposition of CO2 Emissions in China and India for the Period 19802010," in International Conference on Eurasian Economies 2013- Session 7A: Environment \& Regional Economies, 2013, pp. 211-220.

[52] ODYSSEE-MURE, "Energy Efficiency Policies and Measures in UK. ODYSSEE- MURE 2012. Monitoring of EU and national energy efficiency targets.," London, 2012.

[53] G. P. Hammond and J. B. Norman, "Decomposition analysis of energy-related carbon emissions from UK manufacturing," Energy, vol. 41, no. 1, pp. 220-227, 2012.

[54] J. Gaspar, G. Pina, and M. C. N. Simões, "Agriculture in Portugal : linkages with industry and services Agriculture in Portugal : linkages with industry and services."

[55] A. F. Pereira de Lucena, "Uma análise de decomposição das emissões de CO 2 relacionadas ao uso de energia nos setores produtivos brasileiros," in CADMA- $2^{\circ}$ Congresso Acadêmico sobre Meio Ambiente e Desenvolvimento. Área 3: Sociedade e Meio Ambiente, 2006, pp. 3-11.

[56] L. C. Freitas and S. Kaneko, "Decomposing the decoupling of CO2 emissions and economic growth in Brazil,” Ecol. Econ., vol. 70, no. 8, pp. 1459-1469, 2011.

[57] R. Jimenez and J. Mercado, "Energy intensity: A decomposition and counterfactual exercise for Latin American countries," Energy Econ., vol. 42, pp. 161-171, 2014.

[58] IDAE, "Energy Efficiency Policies and Measures in Spain ODYSSEE- MURE 2010 Monitoring of EU and national energy efficiency," Madrid, 2012.

[59] I. I. Conference, "A Structural Decomposition Analysis of Primary Energy Use in Portugal.”

[60] ADENE - Agência para a Energia, "Energy Efficiency Policies and Measures in Portugal ODYSSEEMURE 2010 Monitoring of EU and national energy efficiency targets," Lisbon, 2012.

[61] V. Andreoni and S. Galmarini, "Decoupling economic growth from carbon dioxide emissions: A decomposition analysis of Italian energy consumption,” Energy, vol. 44, no. 1, pp. 682-691, 2012.

[62] G. a. Marrero and F. J. Ramos-Real, "Activity sectors and energy intensity: Decomposition analysis and policy implications for European countries (1991-2005),” Energies, vol. 6, no. 5, pp. 2521-2540, 2013.

[63] United Nations, "We can end poverty- Millennium Development Goals and beyond 2015," 2015. [Online]. Available: http://www.un.org/millenniumgoals/. [Accessed: 01-Dec-2015].

[64] K. Kaygusuz, "Energy for sustainable development: A case of developing countries," Renew. Sustain. Energy Rev., vol. 16, no. 2, pp. 1116-1126, 2012. 


\section{Annex I}

Table A1. Aggregate Decomposition of energy consumption for Brazil

\begin{tabular}{|c|c|c|c|c|}
\hline Brazil & Dact & Dstr & Dint & D tot \\
\hline 1990 & 1.00 & 1.00 & 1.00 & 1.00 \\
\hline 1991 & 1.01 & 1.00 & 1.01 & 1.02 \\
\hline 1992 & 0.99 & 1.00 & 1.02 & 1.01 \\
\hline 1993 & 1.05 & 1.00 & 0.99 & 1.05 \\
\hline 1994 & 1.06 & 1.00 & 0.99 & 1.06 \\
\hline 1995 & 1.03 & 0.99 & 1.02 & 1.04 \\
\hline 1996 & 1.02 & 1.01 & 1.03 & 1.07 \\
\hline 1997 & 1.04 & 1.00 & 1.01 & 1.05 \\
\hline 1998 & 1.00 & 1.00 & 1.04 & 1.04 \\
\hline 1999 & 0.99 & 1.00 & 1.03 & 1.02 \\
\hline 2000 & 1.05 & 1.01 & 0.96 & 1.02 \\
\hline 2001 & 1.00 & 1.01 & 1.00 & 1.02 \\
\hline 2002 & 1.03 & 1.00 & 1.01 & 1.05 \\
\hline 2003 & 1.01 & 1.00 & 1.00 & 1.01 \\
\hline 2004 & 1.07 & 1.00 & 1.00 & 1.06 \\
\hline 2005 & 1.03 & 1.00 & 0.99 & 1.02 \\
\hline 2006 & 1.03 & 0.99 & 1.00 & 1.02 \\
\hline 2007 & 1.06 & 1.00 & 1.01 & 1.07 \\
\hline 2008 & 1.05 & 1.00 & 0.99 & 1.04 \\
\hline 2009 & 0.97 & 0.99 & 1.00 & 0.97 \\
\hline 2010 & 1.08 & 1.00 & 1.02 & 1.11 \\
\hline 2011 & 1.02 & 1.00 & 1.02 & 1.05 \\
\hline 2012 & 1.00 & 1.00 & 1.03 & 1.03 \\
\hline
\end{tabular}


Table A2. Aggregate Decomposition of energy consumption for China

\begin{tabular}{|c|c|c|c|c|}
\hline China & Dact & Dstr & Dint & $D$ tot \\
\hline 1990 & 1.00 & 1.00 & 1.00 & 1.00 \\
\hline 1991 & 1.08 & 1.03 & 0.97 & 1.09 \\
\hline 1992 & 1.14 & 1.04 & 0.92 & 1.09 \\
\hline 1993 & 1.13 & 1.04 & 0.96 & 1.13 \\
\hline 1994 & 1.13 & 1.03 & 0.92 & 1.07 \\
\hline 1995 & 1.11 & 1.02 & 1.00 & 1.13 \\
\hline 1996 & 1.10 & 1.01 & 0.90 & 1.00 \\
\hline 1997 & 1.08 & 1.01 & 0.92 & 1.00 \\
\hline 1998 & 1.08 & 1.01 & 0.97 & 1.05 \\
\hline 1999 & 1.07 & 1.01 & 0.88 & 0.96 \\
\hline 2000 & 1.08 & 1.01 & 0.99 & 1.08 \\
\hline 2001 & 1.07 & 1.01 & 0.95 & 1.03 \\
\hline 2002 & 1.08 & 1.01 & 0.96 & 1.04 \\
\hline 2003 & 1.10 & 1.01 & 1.03 & 1.15 \\
\hline 2004 & 1.10 & 1.01 & 1.09 & 1.21 \\
\hline 2005 & 1.11 & 1.01 & 1.01 & 1.12 \\
\hline 2006 & 1.12 & 1.00 & 0.97 & 1.09 \\
\hline 2007 & 1.13 & 1.01 & 0.95 & 1.08 \\
\hline 2008 & 1.10 & 1.00 & 0.95 & 1.04 \\
\hline 2009 & 1.09 & 1.00 & 0.96 & 1.04 \\
\hline 2010 & 1.11 & 1.00 & 0.98 & 1.09 \\
\hline 2011 & 1.10 & 1.00 & 0.99 & 1.09 \\
\hline 2012 & 1.08 & 1.00 & 0.97 & 1.04 \\
\hline
\end{tabular}


Table A3. Aggregate Decomposition of energy consumption for India

\begin{tabular}{|c|c|c|c|c|}
\hline India & Dact & Dstr & Dint & D tot \\
\hline 1990 & 1.00 & 1.00 & 1.00 & 1.00 \\
\hline 1991 & 0.99 & 1.01 & 1.04 & 1.05 \\
\hline 1992 & 1.05 & 0.99 & 0.97 & 1.02 \\
\hline 1993 & 1.05 & 1.00 & 0.96 & 1.01 \\
\hline 1994 & 1.08 & 1.01 & 0.97 & 1.06 \\
\hline 1995 & 1.07 & 1.03 & 0.96 & 1.05 \\
\hline 1996 & 1.08 & 0.99 & 0.95 & 1.02 \\
\hline 1997 & 1.03 & 1.02 & 1.02 & 1.07 \\
\hline 1998 & 1.06 & 1.00 & 0.96 & 1.01 \\
\hline 1999 & 1.04 & 1.02 & 0.99 & 1.05 \\
\hline 2000 & 1.04 & 1.02 & 0.97 & 1.03 \\
\hline 2001 & 1.06 & 0.99 & 0.94 & 0.99 \\
\hline 2002 & 1.02 & 1.04 & 1.02 & 1.09 \\
\hline 2003 & 1.10 & 1.00 & 0.91 & 1.00 \\
\hline 2004 & 1.08 & 1.03 & 0.98 & 1.09 \\
\hline 2005 & 1.10 & 1.01 & 0.98 & 1.08 \\
\hline 2006 & 1.10 & 1.01 & 0.98 & 1.10 \\
\hline 2007 & 1.09 & 1.01 & 0.98 & 1.08 \\
\hline 2008 & 1.04 & 1.01 & 1.03 & 1.09 \\
\hline 2009 & 1.08 & 1.02 & 1.04 & 1.15 \\
\hline 2010 & 1.10 & 1.00 & 0.99 & 1.09 \\
\hline 2011 & 1.04 & 0.99 & 1.04 & 1.07 \\
\hline 2012 & 1.03 & 1.00 & 1.01 & 1.03 \\
\hline
\end{tabular}


Table A4. Aggregate Decomposition of energy consumption for UK

\begin{tabular}{|c|c|c|c|c|}
\hline$U K$ & Dact & Dstr & Dint & Dtot \\
\hline 1990 & 1.00 & 1.00 & 1.00 & 1.00 \\
\hline 1991 & 0.96 & 1.00 & 1.05 & 1.01 \\
\hline 1992 & 1.01 & 1.00 & 0.97 & 0.99 \\
\hline 1993 & 1.04 & 1.00 & 0.97 & 1.01 \\
\hline 1994 & 1.05 & 1.01 & 0.99 & 1.05 \\
\hline 1995 & 1.03 & 1.01 & 0.97 & 1.00 \\
\hline 1996 & 1.02 & 1.00 & 1.01 & 1.03 \\
\hline 1997 & 1.02 & 1.00 & 0.98 & 1.00 \\
\hline 1998 & 1.03 & 1.01 & 0.97 & 1.00 \\
\hline 1999 & 1.03 & 1.00 & 1.00 & 1.02 \\
\hline 2000 & 1.03 & 1.01 & 0.97 & 1.01 \\
\hline 2001 & 1.01 & 1.00 & 0.99 & 1.00 \\
\hline 2002 & 1.02 & 1.00 & 0.96 & 0.98 \\
\hline 2003 & 1.03 & 1.00 & 0.97 & 1.00 \\
\hline 2004 & 1.02 & 0.99 & 0.97 & 0.99 \\
\hline 2005 & 1.00 & 1.00 & 1.00 & 1.00 \\
\hline 2006 & 1.02 & 1.01 & 0.97 & 1.00 \\
\hline 2007 & 1.02 & 1.00 & 0.97 & 1.00 \\
\hline 2008 & 0.98 & 1.00 & 1.00 & 0.98 \\
\hline 2009 & 0.92 & 1.01 & 1.01 & 0.93 \\
\hline 2010 & 1.03 & 1.00 & 0.98 & 1.01 \\
\hline 2011 & 1.01 & 1.00 & 0.96 & 0.98 \\
\hline 2012 & 0.99 & 1.01 & 1.00 & 1.00 \\
\hline
\end{tabular}


Table A5. Aggregate Decomposition of energy consumption for Spain

\begin{tabular}{|c|c|c|c|c|}
\hline Spain & Dact & Dstr & Dint & Dtot \\
\hline 1990 & 1.00 & 1.00 & 1.00 & 1.00 \\
\hline 1991 & 1.02 & 1.00 & 1.02 & 1.04 \\
\hline 1992 & 0.99 & 1.00 & 1.03 & 1.02 \\
\hline 1993 & 0.97 & 1.00 & 1.01 & 0.99 \\
\hline 1994 & 1.02 & 1.01 & 1.02 & 1.05 \\
\hline 1995 & 1.03 & 0.99 & 1.00 & 1.01 \\
\hline 1996 & 1.02 & 1.00 & 1.00 & 1.03 \\
\hline 1997 & 1.03 & 1.00 & 1.01 & 1.05 \\
\hline 1998 & 1.04 & 1.00 & 1.02 & 1.06 \\
\hline 1999 & 1.04 & 1.00 & 0.99 & 1.04 \\
\hline 2000 & 1.05 & 1.01 & 1.03 & 1.09 \\
\hline 2001 & 1.04 & 1.01 & 1.01 & 1.06 \\
\hline 2002 & 1.02 & 1.00 & 1.00 & 1.02 \\
\hline 2003 & 1.02 & 1.00 & 1.04 & 1.06 \\
\hline 2004 & 1.02 & 1.00 & 1.02 & 1.04 \\
\hline 2005 & 1.02 & 1.00 & 1.01 & 1.03 \\
\hline 2006 & 1.03 & 1.00 & 0.92 & 0.94 \\
\hline 2007 & 1.03 & 1.01 & 1.01 & 1.05 \\
\hline 2008 & 1.00 & 1.00 & 0.96 & 0.96 \\
\hline 2009 & 0.94 & 1.01 & 0.96 & 0.92 \\
\hline 2010 & 0.99 & 1.02 & 1.00 & 1.02 \\
\hline 2011 & 0.99 & 1.01 & 0.99 & 0.99 \\
\hline 2012 & 0.96 & 1.02 & 0.99 & 0.97 \\
\hline
\end{tabular}


Table A6. Aggregate Decomposition of energy consumption for Portugal

\begin{tabular}{|c|c|c|c|c|}
\hline Portugal & Dact & Dstr & Dint & Dtot \\
\hline 1990 & 1.00 & 1.00 & 1.00 & 1.00 \\
\hline 1991 & 1.01 & 1.00 & 1.03 & 1.04 \\
\hline 1992 & 1.00 & 1.01 & 1.04 & 1.04 \\
\hline 1993 & 0.99 & 1.01 & 1.02 & 1.02 \\
\hline 1994 & 1.02 & 1.01 & 1.04 & 1.07 \\
\hline 1995 & 1.02 & 1.01 & 1.01 & 1.04 \\
\hline 1996 & 1.04 & 1.00 & 1.00 & 1.04 \\
\hline 1997 & 1.05 & 0.99 & 1.01 & 1.06 \\
\hline 1998 & 1.04 & 1.00 & 1.05 & 1.09 \\
\hline 1999 & 1.04 & 1.01 & 1.00 & 1.05 \\
\hline 2000 & 1.04 & 1.01 & 1.02 & 1.08 \\
\hline 2001 & 1.02 & 1.01 & 1.00 & 1.03 \\
\hline 2002 & 1.00 & 1.01 & 1.03 & 1.04 \\
\hline 2003 & 0.98 & 1.01 & 1.01 & 0.99 \\
\hline 2004 & 1.02 & 1.01 & 0.99 & 1.02 \\
\hline 2005 & 0.99 & 1.01 & 1.01 & 1.01 \\
\hline 2006 & 1.02 & 1.01 & 0.97 & 0.99 \\
\hline 2007 & 1.02 & 1.02 & 1.00 & 1.04 \\
\hline 2008 & 0.99 & 1.01 & 0.98 & 0.98 \\
\hline 2009 & 0.95 & 1.00 & 1.03 & 0.98 \\
\hline 2010 & 1.02 & 1.00 & 0.98 & 1.00 \\
\hline 2011 & 0.99 & 1.01 & 0.96 & 0.96 \\
\hline 2012 & 0.97 & 1.00 & 0.95 & 0.92 \\
\hline
\end{tabular}




\section{Annex II}

Table A7- China Policy Scope: Energy Efficiency; RES and Climate Change Framework between 1990 and 2012(adapted from: IEA, 2016)

\begin{tabular}{|c|c|c|c|c|c|c|c|c|c|c|}
\hline \multicolumn{11}{|c|}{ Energy Efficiency } \\
\hline \multicolumn{2}{|c|}{ Key Years } & \multirow{2}{*}{\begin{tabular}{l}
\multicolumn{1}{c}{2004} \\
Long-term \\
Plan of \\
Energy \\
Conservation: \\
10 Energy \\
Conservation \\
Programmes
\end{tabular}} & \multirow{2}{*}{\begin{tabular}{l}
\multicolumn{1}{c}{2005} \\
Vehicle \\
Fuel \\
Economy \\
Standards
\end{tabular}} & 2006 & \multirow{2}{*}{$\begin{array}{l}\quad 2007 \\
\text { National } \\
\text { Climate } \\
\text { Change } \\
\text { Program }\end{array}$} & \multirow{2}{*}{\begin{tabular}{l}
\multicolumn{1}{c}{2008} \\
Energy \\
Conservatio \\
n Law
\end{tabular}} & \multirow{2}{*}{\begin{tabular}{l}
\multicolumn{1}{c}{2009} \\
Government \\
Promotion of \\
Energy \\
Efficient \\
Products
\end{tabular}} & \multirow{2}{*}{\begin{tabular}{l}
\multicolumn{1}{c}{2010} \\
Demand-Side \\
Management \\
Implementatio \\
n Measures
\end{tabular}} & 2011 & \multirow[b]{2}{*}{$\begin{array}{l}\text { Energy } \\
\text { new } \\
\text { automot } \\
\text { developi } \\
2012-20\end{array}$} \\
\hline \multirow{4}{*}{ 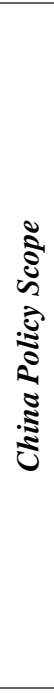 } & Title & & & $\begin{array}{l}\text { General Work } \\
\text { Plan for } \\
\text { Energy } \\
\text { Conservation } \\
\text { and Pollutant } \\
\text { Discharge } \\
\text { Reduction }\end{array}$ & & & & & $\begin{array}{l}\text { The Twelfth } \\
\text { Five-Year Plan } \\
\text { for National } \\
\text { Economic and } \\
\text { Social } \\
\text { Development of } \\
\text { The Peoples } \\
\text { Republic of } \\
\text { China }\end{array}$ & \\
\hline & Status & $\square$ & $\square$ & $\square$ & $\square$ & $\square$ & $\square$ & $\square$ & $\square$ & $\square$ \\
\hline & Type & $\begin{array}{l}\text { Regulatory } \\
\text { Instruments }\end{array}$ & $\begin{array}{l}\text { Regulatory } \\
\text { Instruments }\end{array}$ & $\begin{array}{l}\text { Regulatory } \\
\text { Instruments }\end{array}$ & $\begin{array}{l}\text { Policy } \\
\text { Support/ } \\
\text { Strategic } \\
\text { planning }\end{array}$ & & $\begin{array}{l}\text { Economic } \\
\text { Instrument }\end{array}$ & $\begin{array}{l}\text { Regulatory } \\
\text { Instruments }\end{array}$ & $\begin{array}{c}\text { Policy Support/ } \\
\text { Strategic } \\
\text { planning }\end{array}$ & $\begin{array}{c}\text { Policy Support/ } \\
\text { Strategic planning }\end{array}$ \\
\hline & $\begin{array}{l}\text { Targe } \\
\mathbf{t}\end{array}$ & $\begin{array}{l}\text { Transport } \\
\text { Sector }\end{array}$ & $\begin{array}{l}\text { Transport } \\
\text { Sector }\end{array}$ & $\begin{array}{l}\text { Lighting, } \\
\text { Buildings, } \\
\text { Energy } \\
\text { Utilities }\end{array}$ & $\begin{array}{l}\text { Cross - } \\
\text { Sector }\end{array}$ & $\begin{array}{l}\text { Cross - } \\
\text { Sector }\end{array}$ & Cross- Sector & $\begin{array}{l}\text { Energy } \\
\text { Utilities }\end{array}$ & Cross- Sector & Transport Sector \\
\hline \multicolumn{11}{|c|}{ Renewable Energy Sources (RES) } \\
\hline \multicolumn{2}{|c|}{ Key Years } & 2003 & 2006 & 2009 & 2010 & - & - & - & - & - \\
\hline \multirow{3}{*}{ 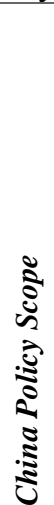 } & Title & $\begin{array}{l}\text { Wind Power } \\
\text { Concession } \\
\text { Programme }\end{array}$ & $\begin{array}{l}\text { Support for } \\
\text { Biogas } \\
\text { Projects }\end{array}$ & $\begin{array}{l}\text { Notice on the } \\
\text { removal of } \\
\text { local content } \\
\text { requirement in } \\
\text { wind power } \\
\text { projects } \\
\text { equipments } \\
\text { procurement }\end{array}$ & $\begin{array}{l}\text { Building } \\
\text { Integrate } \\
\text { Solar PV } \\
\text { Programme }\end{array}$ & - & - & - & - & - \\
\hline & Status & $x$ & $\square$ & $\square$ & $\square$ & - & - & - & - & - \\
\hline & Type & $\begin{array}{l}\text { Economic } \\
\text { Instrument }\end{array}$ & $\begin{array}{l}\text { Policy } \\
\text { Support/ } \\
\text { Strategic } \\
\text { planning }\end{array}$ & $\begin{array}{l}\text { Policy } \\
\text { Support/ } \\
\text { Strategic } \\
\text { planning }\end{array}$ & $\begin{array}{l}\text { Economic } \\
\text { Instrument }\end{array}$ & - & - & - & - & - \\
\hline
\end{tabular}




\begin{tabular}{|c|c|c|c|c|c|c|c|c|c|c|}
\hline & $\begin{array}{l}\text { Targe } \\
t\end{array}$ & Wind Power & Bioenergy & Wind Power & Solar Power & - & - & - & - & - \\
\hline \multicolumn{2}{|c|}{ Key Years } & \multicolumn{9}{|c|}{ Climate Change } \\
\hline \multirow{5}{*}{ 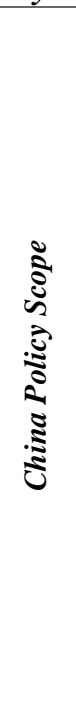 } & & 2004 & 2005 & 2006 & 2007 & 2008 & 2009 & 2010 & 2011 & 2012 \\
\hline & Title & $\begin{array}{l}\text { Long-term } \\
\text { Plan of } \\
\text { Energy } \\
\text { Conservation: } \\
10 \text { Energy } \\
\text { Conservation } \\
\text { Programmes }\end{array}$ & $\begin{array}{l}\text { Vehicle } \\
\text { Fuel } \\
\text { Economy } \\
\text { Standards }\end{array}$ & \begin{tabular}{lr}
\multicolumn{2}{l}{ Renewable } \\
Energy Law \\
(revised & in \\
$2009)$ &
\end{tabular} & $\begin{array}{l}\text { National } \\
\text { Climate } \\
\text { Change } \\
\text { Program }\end{array}$ & $\begin{array}{l}\text { National } \\
\text { Building } \\
\text { Energy } \\
\text { Standard }\end{array}$ & $\begin{array}{l}\text { Government } \\
\text { Promotion of } \\
\text { Energy } \\
\text { Efficient } \\
\text { Products }\end{array}$ & $\begin{array}{l}\text { Copenhagen } \\
\text { Accord pledge } \\
\text { of China }\end{array}$ & $\begin{array}{l}\text { The Twelfth } \\
\text { Five-Year Plan } \\
\text { for National } \\
\text { Economic and } \\
\text { Social } \\
\text { Development of } \\
\text { The Peoples } \\
\text { Republic of } \\
\text { China }\end{array}$ & $\begin{array}{l}\text { Differential Energy } \\
\text { Pricing }\end{array}$ \\
\hline & Status & $\square$ & $\square$ & $\square$ & $\square$ & $\square$ & $\square$ & $\square$ & $\square$ & $\square$ \\
\hline & Type & $\begin{array}{l}\text { Regulatory } \\
\text { Instruments }\end{array}$ & $\begin{array}{l}\text { Regulatory } \\
\text { Instruments }\end{array}$ & $\begin{array}{l}\text { Policy } \\
\text { Support/ } \\
\text { Strategic } \\
\text { planning }\end{array}$ & $\begin{array}{l}\text { Policy } \\
\text { Support/ } \\
\text { Strategic } \\
\text { planning }\end{array}$ & $\begin{array}{l}\text { Regulatory } \\
\text { Instruments }\end{array}$ & $\begin{array}{l}\text { Economic } \\
\text { Instrument }\end{array}$ & $\begin{array}{l}\text { Policy } \\
\text { Support/ } \\
\text { Strategic } \\
\text { planning }\end{array}$ & $\begin{array}{l}\text { Policy Support/ } \\
\text { Strategic } \\
\text { planning }\end{array}$ & $\begin{array}{l}\text { Economic } \\
\text { Instruments }\end{array}$ \\
\hline & $\begin{array}{l}\text { Targe } \\
\text { t }\end{array}$ & $\begin{array}{l}\text { Transport } \\
\text { Sector }\end{array}$ & $\begin{array}{l}\text { Transport } \\
\text { Sector }\end{array}$ & Energy Sector & $\begin{array}{l}\text { Cross- } \\
\text { Sector }\end{array}$ & $\begin{array}{l}\text { Buildings, } \\
\text { Residential } \\
\text { Sector }\end{array}$ & Cross- Sector & Cross - Sector & Cross- Sector & Cross- Sector \\
\hline
\end{tabular}


Table A8- India Policy Scope: Energy Efficiency; RES and Climate Change Framework between 1990 and 2012 (adapted from: IEA, 2016) Energy Efficiency

\begin{tabular}{|c|c|c|c|c|c|c|c|c|c|c|}
\hline \multicolumn{2}{|c|}{ Key Years } & 2004 & 2005 & 2006 & 2007 & 2008 & 2009 & 2010 & 2011 & 2012 \\
\hline \multirow{5}{*}{ 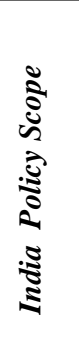 } & Title & & & & & & & & & \\
\hline & & - & - & - & - & - & - & - & - & - \\
\hline & Status & - & - & - & - & - & - & - & - & - \\
\hline & Type & - & - & - & - & - & - & - & - & - \\
\hline & $\begin{array}{l}\text { Targe } \\
\mathbf{t}\end{array}$ & - & - & - & - & - & - & - & - & - \\
\hline \multicolumn{11}{|c|}{ Renewable Energy Sources (RES) } \\
\hline \multicolumn{2}{|c|}{ Key Years } & 2002 & 2003 & 2006 & 2008 & 2009 & 2010 & 2011 & - & - \\
\hline \multirow{4}{*}{ 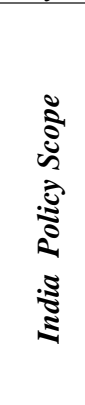 } & Title & $\begin{array}{c}\text { Government } \\
\text { Assistance } \\
\text { for Wind } \\
\text { Power } \\
\text { Development }\end{array}$ & $\begin{array}{l}\text { Government } \\
\text { Assistance for } \\
\text { Small } \\
\text { Hydropower } \\
\text { Stations }\end{array}$ & $\begin{array}{c}\text { Tariff Policy } \\
2006\end{array}$ & $\begin{array}{l}\text { Generation based } \\
\text { incentives for } \\
\text { wind power }\end{array}$ & $\begin{array}{l}\text { RE Tariff } \\
\text { regulations }\end{array}$ & $\begin{array}{l}\text { National Solar } \\
\text { Mission } \\
\text { (Phase I and } \\
\text { II) }\end{array}$ & $\begin{array}{l}\text { Renewable } \\
\text { Energy } \\
\text { Certificates } \\
\text { system }\end{array}$ & - & - \\
\hline & Status & $\square$ & $\square$ & $\square$ & $\square$ & $\square$ & $\square$ & $\square$ & - & - \\
\hline & Type & $\begin{array}{l}\text { Economic } \\
\text { Instrument }\end{array}$ & $\begin{array}{l}\text { Economic } \\
\text { Instrument }\end{array}$ & $\begin{array}{l}\text { Regulatory } \\
\text { Instrument }\end{array}$ & $\begin{array}{l}\text { Economic } \\
\text { Instrument }\end{array}$ & $\begin{array}{l}\text { Economic } \\
\text { Instrument }\end{array}$ & $\begin{array}{l}\text { Regulatory } \\
\text { Instrument }\end{array}$ & $\begin{array}{l}\text { Economic } \\
\text { Instrument }\end{array}$ & - & - \\
\hline & $\begin{array}{l}\text { Targe } \\
\mathbf{t}\end{array}$ & Wind Power & Hydropower & $\begin{array}{c}\text { Multiple } \\
\text { Alternatives }\end{array}$ & Wind Power & $\begin{array}{c}\text { Multiple } \\
\text { Alternatives }\end{array}$ & Solar Power & $\begin{array}{c}\text { Multiple } \\
\text { Alternatives }\end{array}$ & - & - \\
\hline \multicolumn{2}{|c|}{ Key Years } & \multicolumn{9}{|c|}{ Climate Change } \\
\hline \multirow{3}{*}{ 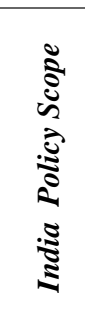 } & & 2003 & 2006 & 2007 & 2008 & 2009 & 2010 & - & - & - \\
\hline & Title & $\begin{array}{l}\text { Electricity } \\
\text { Act }\end{array}$ & $\begin{array}{c}\text { Tariff Policy } \\
2006\end{array}$ & $\begin{array}{c}\text { Energy } \\
\text { Conservation } \\
\text { Building Code } \\
\text { (ECBC) }\end{array}$ & $\begin{array}{l}\text { National Action } \\
\text { Plan on Climate } \\
\text { Change }\end{array}$ & $\begin{array}{l}\text { RE Tariff } \\
\text { regulations }\end{array}$ & $\begin{array}{l}\text { National Solar } \\
\text { Mission } \\
\text { (Phase I and } \\
\text { II) }\end{array}$ & - & - & - \\
\hline & Status & & & & & $\square$ & & - & - & - \\
\hline
\end{tabular}




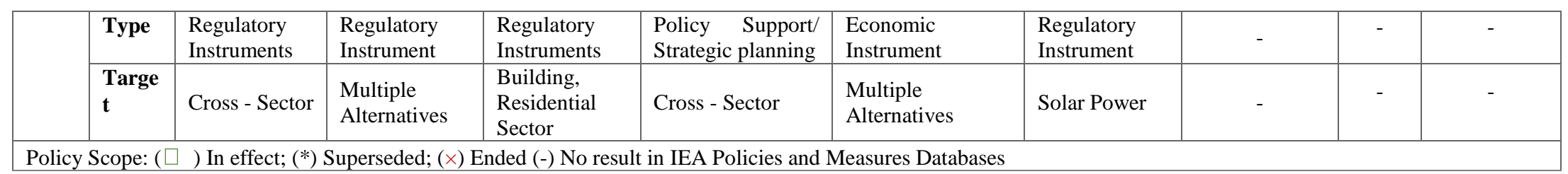


Table A9- Brazil Policy Scope: Energy Efficiency; RES and Climate Change Framework between 1990 and 2012 (adapted from: IEA, 2016)

\begin{tabular}{|c|c|c|c|c|c|c|c|c|c|c|}
\hline \multicolumn{11}{|c|}{ Energy Efficiency } \\
\hline \multicolumn{2}{|c|}{ Key Years } & 1993 & 1997 & 1998 & 2003 & - & - & - & - & . \\
\hline \multirow{4}{*}{ 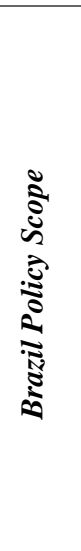 } & Title & $\begin{array}{l}\text { PROCEL } \\
\text { Label }\end{array}$ & $\begin{array}{c}\text { Energy } \\
\text { Efficiency } \\
\text { Program in } \\
\text { Public } \\
\text { Buildings } \\
\text { - PROCEL } \\
\text { EPP }\end{array}$ & $\begin{array}{c}\text { Energy Efficiency } \\
\text { Programme of the } \\
\text { Electricity distribution } \\
\text { Companies }\end{array}$ & $\begin{array}{l}\text { PROCEL } \\
\text { Industry }\end{array}$ & - & - & - & - & - \\
\hline & Status & $\square$ & $\square$ & $\square$ & $\square$ & - & - & - & - & - \\
\hline & Type & $\begin{array}{l}\text { Regulatory } \\
\text { Instruments }\end{array}$ & $\begin{array}{l}\text { Development } \\
\text { and } \\
\text { Deployment } \\
\text { (RD\&D) }\end{array}$ & Economic Instruments & $\begin{array}{l}\text { Economic } \\
\text { Instruments }\end{array}$ & - & - & - & - & - \\
\hline & $\begin{array}{l}\text { Targe } \\
\mathbf{t}\end{array}$ & $\begin{array}{l}\text { Residential } \\
\text { Appliances }\end{array}$ & $\begin{array}{l}\text { Transport } \\
\text { Sector }\end{array}$ & Buildings & Industry Sector & - & - & - & - & - \\
\hline \multicolumn{11}{|c|}{ Renewable Energy Sources (RES) } \\
\hline \multicolumn{2}{|c|}{ Key Years } & 2008 & 2009 & 2010 & 2011 & - & - & - & - & - \\
\hline \multirow{4}{*}{ 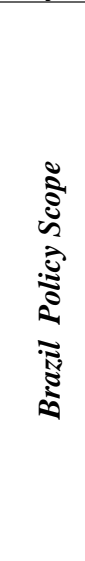 } & Title & $\begin{array}{l}\text { Electric } \\
\text { power } \\
\text { auctions } \\
\text { Biomass }\end{array}$ & $\begin{array}{l}\text { Electric power } \\
\text { auctions } \\
\text { Wind }\end{array}$ & $\begin{array}{l}\text { 2010-2019 Plan for } \\
\text { Energy } \\
\text { Expansion }\end{array}$ & $\begin{array}{c}\text { Ethanol export tax } \\
\text { credit - } \\
\text { Regime Especial de } \\
\text { Reintegração } \\
\text { de Valores } \\
\text { Tributários para as } \\
\text { Empresas } \\
\text { Exportadoras - } \\
\text { REINTEGRA }\end{array}$ & - & - & - & - & - \\
\hline & Status & $\square$ & $\square$ & $\square$ & $\square$ & - & - & - & - & 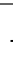 \\
\hline & Type & $\begin{array}{l}\text { Regulatory } \\
\text { Instrument }\end{array}$ & $\begin{array}{l}\text { Regulatory } \\
\text { Instrument }\end{array}$ & Economic Instrument & $\begin{array}{l}\text { Economic } \\
\text { Instrument }\end{array}$ & - & - & - & - & - \\
\hline & $\begin{array}{l}\text { Targe } \\
\mathbf{t}\end{array}$ & Bioenergy & Wind Power & Multiple Alternatives & Bioenergy & - & - & - & - & . \\
\hline \multicolumn{2}{|c|}{ Key Years } & \multicolumn{9}{|c|}{ Climate Change } \\
\hline
\end{tabular}




\begin{tabular}{|c|c|c|c|c|c|c|c|c|c|c|}
\hline \multirow{5}{*}{ 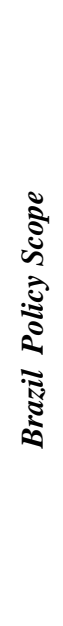 } & & 1993 & 1997 & 1998 & 1999 & 2005 & 2009 & 2010 & - & - \\
\hline & Title & $\begin{array}{l}\text { National } \\
\text { Electricity } \\
\text { Conservation } \\
\text { Program - } \\
\text { PROCEL }\end{array}$ & $\begin{array}{l}\text { Energy } \\
\text { Efficiency } \\
\text { Program in } \\
\text { Public } \\
\text { Buildings } \\
-\quad \text { PROCEL } \\
\text { EPP }\end{array}$ & $\begin{array}{l}\text { PROCEL } \\
\text { Municipal } \\
\text { Energy } \\
\text { Management }\end{array}$ & $\begin{array}{l}\text { Interministerial } \\
\text { Commission } \\
\text { on Climate } \\
\text { Change } \\
\text { (CIMGC) }\end{array}$ & $\begin{array}{l}\text { Mandatory } \\
\text { Biodiesel } \\
\text { Requirement }\end{array}$ & $\begin{array}{l}\text { Electric } \\
\text { power } \\
\text { auctions } \quad- \\
\text { Wind }\end{array}$ & $\begin{array}{l}\text { Copenhagen } \\
\text { Accord pledge } \\
\text { of Brazil }\end{array}$ & - & - \\
\hline & Status & $\square$ & $\square$ & $\square$ & $\square$ & $\square$ & $\square$ & $\square$ & - & - \\
\hline & Type & $\begin{array}{l}\text { Regulatory } \\
\text { Instruments }\end{array}$ & $\begin{array}{l}\text { Development } \\
\text { and } \\
\text { Deployment } \\
\text { (RD\&D) }\end{array}$ & $\begin{array}{l}\text { Information/ } \\
\text { Education }\end{array}$ & $\begin{array}{l}\text { Information/ } \\
\text { Education }\end{array}$ & $\begin{array}{l}\text { Regulatory } \\
\text { Instruments }\end{array}$ & $\begin{array}{l}\text { Regulatory } \\
\text { Instrument }\end{array}$ & $\begin{array}{l}\text { Policy } \\
\text { Support/ } \\
\text { Strategic } \\
\text { planning }\end{array}$ & - & - \\
\hline & $\begin{array}{l}\text { Targe } \\
\text { t }\end{array}$ & Energy Sector & $\begin{array}{l}\text { Transport } \\
\text { Sector }\end{array}$ & Cross - Sector & Cross- Sector & $\begin{array}{l}\text { Transport } \\
\text { Sector }\end{array}$ & $\begin{array}{l}\text { Energy } \\
\text { Sector }\end{array}$ & Cross - Sector & - & - \\
\hline
\end{tabular}


Table A10- United Kingdom Policy Scope: Energy Efficiency; RES and Climate Change Framework between 1990 and 2012 (adapted from: IEA, 2016)

\begin{tabular}{|c|c|c|c|c|c|c|c|c|c|c|}
\hline \multicolumn{11}{|c|}{ Energy Efficiency } \\
\hline \multicolumn{2}{|c|}{ Key Years } & 1998 & \multirow{2}{*}{$\begin{array}{l}\quad \text { 2001 } \\
\text { Climate } \\
\text { Change } \\
\text { Agreements }\end{array}$} & \multirow{2}{*}{$\begin{array}{l}\qquad 006 \\
\qquad \text { Climate Change } \\
\text { and Sustainable } \\
\text { Energy Act }\end{array}$} & 2007 & \multirow{2}{*}{$\begin{array}{l}\quad 2008 \\
\text { Carbon } \\
\text { Emissions } \\
\text { Reduction } \\
\text { Target (Energy } \\
\text { Efficiency } \\
\text { Commitment 3) }\end{array}$} & \multirow{2}{*}{$\begin{array}{l}\quad 2009 \\
\text { Community } \\
\text { Energy } \\
\text { Savings } \\
\text { Programme } \\
\text { (CESP) }\end{array}$} & \multirow{2}{*}{\begin{tabular}{l}
\multicolumn{1}{c}{2010} \\
Carbon \\
Reduction \\
Commitm \\
ent Energy \\
Efficiency \\
Scheme \\
(CRC)
\end{tabular}} & - & \multirow[t]{2}{*}{-} \\
\hline \multirow{4}{*}{$\begin{array}{l}5 \\
\vdots \\
\vdots \\
\vdots \\
\vdots \\
\vdots \\
2 \\
\vdots \\
5\end{array}$} & Title & $\begin{array}{l}\text { White Paper: } \\
\text { A New Deal } \\
\text { for Transport }\end{array}$ & & & $\begin{array}{l}\text { Stamp Duty } \\
\text { Relief for Zero } \\
\text { Carbon Homes }\end{array}$ & & & & - & \\
\hline & Status & $*$ & $\square$ & $\times$ & $x$ & $x$ & $*$ & $\square$ & - & - \\
\hline & Type & $\begin{array}{l}\text { Policy } \\
\text { Support }\end{array}$ & $\begin{array}{l}\text { Voluntary } \\
\text { Approaches }\end{array}$ & Policy Support & $\begin{array}{l}\text { Economic } \\
\text { Instrument }\end{array}$ & $\begin{array}{l}\text { Regulatory } \\
\text { Instrument }\end{array}$ & $\begin{array}{l}\text { Economic } \\
\text { Instrument }\end{array}$ & $\begin{array}{l}\text { Regulator } \\
\text { y industry }\end{array}$ & - & - \\
\hline & $\begin{array}{l}\text { Targe } \\
\mathbf{t}\end{array}$ & $\begin{array}{l}\text { Transport } \\
\text { Sector }\end{array}$ & $\begin{array}{l}\text { Industry } \\
\text { Sector }\end{array}$ & $\begin{array}{l}\text { Multiple } \\
\text { Alternatives }\end{array}$ & $\begin{array}{l}\text { Residential } \\
\text { Sector }\end{array}$ & Industry Sector & Buildings & $\begin{array}{l}\text { Industry } \\
\text { sector }\end{array}$ & - & - \\
\hline \multicolumn{11}{|c|}{ Renewable Energy Sources (RES) } \\
\hline \multicolumn{2}{|c|}{ Key Years } & 2001 & 2002 & 2003 & 2004 & 2006 & 2008 & 2009 & 2010 & 2011 \\
\hline \multirow{4}{*}{ 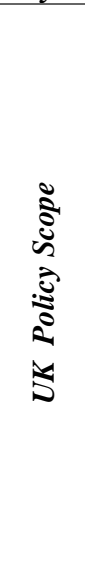 } & Title & $\begin{array}{l}\text { Climate } \\
\text { Change Levy } \\
\text { (updated } \\
\text { 2015) }\end{array}$ & $\begin{array}{l}\text { Renewables } \\
\text { Obligation } \\
\text { (RO) }\end{array}$ & $\begin{array}{l}\text { Renewable } \\
\text { Energy } \\
\text { Guarantees of } \\
\text { Origin (REGOs) }\end{array}$ & $\begin{array}{l}\text { Energy Act } \\
2004\end{array}$ & $\begin{array}{l}\text { Climate Change } \\
\text { and Sustainable } \\
\text { Energy Act }\end{array}$ & $\begin{array}{l}\text { Energy } \quad \text { Act } \\
2008\end{array}$ & $\begin{array}{l}\text { Renewabl } \\
\text { e Energy } \\
\text { Strategy } \\
2009\end{array}$ & $\begin{array}{l}\text { Feed-in } \\
\text { Tariffs for } \\
\text { renewable } \\
\text { electricity for } \\
\text { PV and non- } \\
\text { PV } \\
\text { technologies }\end{array}$ & $\begin{array}{l}\text { Renewable } \\
\text { Heat } \\
\text { Incentive } \\
\text { (RHI) for } \\
\text { domestic } \\
\text { and non- } \\
\text { domestic } \\
\text { generators }\end{array}$ \\
\hline & Status & $\square$ & $\square$ & $\square$ & $\square$ & $x$ & $\square$ & $\square$ & $\square$ & $\square$ \\
\hline & Type & $\begin{array}{l}\text { Economic } \\
\text { Instrument }\end{array}$ & $\begin{array}{l}\text { Economic } \\
\text { Instrument }\end{array}$ & $\begin{array}{l}\text { Information/Edu } \\
\text { cation }\end{array}$ & $\begin{array}{l}\text { Regulatory } \\
\text { Instrument }\end{array}$ & Policy Support & $\begin{array}{l}\text { Policy } \\
\text { Support }\end{array}$ & $\begin{array}{l}\text { Economic } \\
\text { Instrumen } \\
\mathrm{t}\end{array}$ & $\begin{array}{l}\text { Economic } \\
\text { Instrument }\end{array}$ & $\begin{array}{l}\text { Economic } \\
\text { Instrument }\end{array}$ \\
\hline & $\begin{array}{l}\text { Targe } \\
\mathrm{t}\end{array}$ & $\begin{array}{l}\text { Multiple } \\
\text { Alternatives }\end{array}$ & $\begin{array}{l}\text { Multiple } \\
\text { Alternatives }\end{array}$ & $\begin{array}{l}\text { Multiple } \\
\text { Alternatives }\end{array}$ & $\begin{array}{l}\text { Multiple } \\
\text { Alternatives }\end{array}$ & $\begin{array}{l}\text { Multiple } \\
\text { Alternatives }\end{array}$ & Solar Power & $\begin{array}{l}\text { Multiple } \\
\text { Alternativ } \\
\text { es }\end{array}$ & $\begin{array}{l}\text { Multiple } \\
\text { Alternatives }\end{array}$ & $\begin{array}{l}\text { Multiple } \\
\text { Alternatives }\end{array}$ \\
\hline \multicolumn{2}{|c|}{ Key Years } & \multicolumn{9}{|c|}{ Climate Change } \\
\hline$\underset{5}{2}:$ & & 2001 & 2002 & 2004 & 2006 & 2008 & 2009 & 2010 & 2011 & - \\
\hline
\end{tabular}




\begin{tabular}{|c|c|c|c|c|c|c|c|c|c|c|}
\hline & Title & $\begin{array}{l}\text { Climate } \\
\text { Change Levy } \\
\text { (updated } \\
\text { 2015) }\end{array}$ & $\begin{array}{l}\text { Renewables } \\
\text { Obligation } \\
\text { (RO) }\end{array}$ & $\begin{array}{l}\text { Energy Act } \\
2004\end{array}$ & $\begin{array}{l}\text { Climate Change } \\
\text { and Sustainable } \\
\text { Energy Act }\end{array}$ & $\begin{array}{l}\text { Renewable } \\
\text { Transport Fuels } \\
\text { Obligation } \\
\text { (RTFO) }\end{array}$ & $\begin{array}{l}\text { Renewable } \\
\text { Energy } \\
\text { Strategy } 2009\end{array}$ & $\begin{array}{l}\text { Feed-in Tariffs } \\
\text { for renewable } \\
\text { electricity for } \\
\mathrm{PV} \text { and non-PV } \\
\text { technologies }\end{array}$ & $\begin{array}{c}\text { Carbon } \\
\text { Plan }\end{array}$ & - \\
\hline & Status & $\square$ & $\square$ & & $x$ & $x$ & $\square$ & $\square$ & $\square$ & - \\
\hline & Type & $\begin{array}{l}\text { Economic } \\
\text { Instrument }\end{array}$ & $\begin{array}{l}\text { Economic } \\
\text { Instrument }\end{array}$ & $\begin{array}{l}\text { Regulatory } \\
\text { Instrument }\end{array}$ & Policy Support & $\begin{array}{l}\text { Regulatory } \\
\text { Instrument }\end{array}$ & $\begin{array}{l}\text { Economic } \\
\text { Instrument }\end{array}$ & $\begin{array}{l}\text { Economic } \\
\text { Instrument }\end{array}$ & $\begin{array}{l}\text { Policy } \\
\text { Support }\end{array}$ & - \\
\hline & $\begin{array}{l}\text { Targe } \\
\text { t }\end{array}$ & $\begin{array}{l}\text { Multiple } \\
\text { Alternatives }\end{array}$ & $\begin{array}{l}\text { Multiple } \\
\text { Alternatives }\end{array}$ & $\begin{array}{l}\text { Multiple } \\
\text { Alternatives }\end{array}$ & $\begin{array}{l}\text { Climate Change } \\
\text { and Sustainable } \\
\text { Energy Act }\end{array}$ & Cross - Sector & $\begin{array}{l}\text { Multiple } \\
\text { Alternatives }\end{array}$ & $\begin{array}{l}\text { Multiple } \\
\text { Alternatives }\end{array}$ & $\begin{array}{l}\text { Cross - } \\
\text { sector }\end{array}$ & - \\
\hline
\end{tabular}


Table A11- Portugal Policy Scope: Energy Efficiency; RES and Climate Change Framework between 1990 and 2012 (adapted from: IEA, 2016)

\begin{tabular}{|c|c|c|c|c|c|c|c|c|c|c|}
\hline \multicolumn{11}{|c|}{ Energy Efficiency } \\
\hline \multicolumn{2}{|c|}{ Key Years } & 2008 & - & - & & - & - & - & - & - \\
\hline \multirow{4}{*}{ 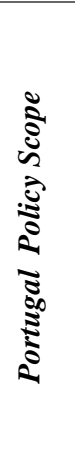 } & Title & $\begin{array}{l}\text { Management } \\
\text { System of } \\
\text { Intensive } \\
\text { Energy } \\
\text { Consumption } \\
\text { (SGCIE) }\end{array}$ & - & - & - & \multicolumn{2}{|c|}{-} & - & - & - \\
\hline & Status & $\square$ & - & - & - & \multicolumn{2}{|c|}{-} & - & - & - \\
\hline & Type & $\begin{array}{l}\text { Regulatory } \\
\text { Instrument }\end{array}$ & - & - & - & \multicolumn{2}{|c|}{-} & - & - & - \\
\hline & $\begin{array}{l}\text { Targe } \\
\text { t }\end{array}$ & $\begin{array}{l}\text { Industry } \\
\text { sector }\end{array}$ & - & - & - & \multicolumn{2}{|c|}{-} & - & - & - \\
\hline \multicolumn{11}{|c|}{ Renewable Energy Sources (RES) } \\
\hline \multicolumn{2}{|c|}{ Key Years } & 2008 & 2009 & 2010 & 2011 & \multicolumn{2}{|l|}{-} & - & - & - \\
\hline \multirow{4}{*}{ 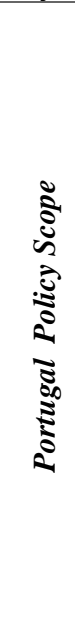 } & Title & $\begin{array}{c}\text { Wave Energy } \\
\text { Pilot } \\
\text { Zone }\end{array}$ & $\begin{array}{l}\text { Solar thermal } \\
\text { incentive } \\
\text { scheme } \\
2009\end{array}$ & $\begin{array}{l}\text { National } \\
\text { Renewable } \\
\text { Energy } \\
\text { action } \\
\text { Plan } \\
\text { (NREAP) }\end{array}$ & $\begin{array}{c}\text { Mini } \\
\text { Production } \\
\text { Law } \\
\text { amendment } \\
\text { (Decree Law } \\
\text { 34/2011) } \\
\end{array}$ & - & - & - & - & - \\
\hline & Status & $\square$ & $x$ & $*$ & $\square$ & - & - & - & - & - \\
\hline & Type & $\begin{array}{c}\text { Regulatory } \\
\text { Instruments, } \\
\text { Research, } \\
\text { Development } \\
\text { and } \\
\text { Deployment } \\
\text { (RD\&D) }\end{array}$ & $\begin{array}{l}\text { Economic } \\
\text { Instrument }\end{array}$ & $\begin{array}{l}\text { Regulatory } \\
\text { Instrument }\end{array}$ & $\begin{array}{l}\text { Economic } \\
\text { Instrument }\end{array}$ & - & - & - & - & - \\
\hline & $\begin{array}{l}\text { Targe } \\
\mathbf{t}\end{array}$ & Ocean & Solar Thermal & $\begin{array}{l}\text { Multiple } \\
\text { Alternatives }\end{array}$ & $\begin{array}{l}\text { Multiple } \\
\text { Alternatives }\end{array}$ & - & - & - & - & - \\
\hline \multicolumn{2}{|c|}{ Key Years } & \multicolumn{9}{|c|}{ Climate Change } \\
\hline \multicolumn{2}{|c|}{ 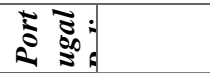 } & 1991 & 2001 & 2005 & 2006 & 2007 & 2008 & 2009 & 2010 & 2011 \\
\hline
\end{tabular}




\begin{tabular}{|c|c|c|c|c|c|c|c|c|c|c|}
\hline & Title & $\begin{array}{l}\text { Management } \\
\text { Regulation of } \\
\text { Energy } \\
\text { Consumption } \\
\text { in Transport } \\
\text { (RGCEST) }\end{array}$ & $\begin{array}{c}\text { Energy } \\
\text { Efficiency and } \\
\text { Endogenous } \\
\text { Energies (E4) } \\
\text { Programme }\end{array}$ & $\begin{array}{l}\text { National } \\
\text { Energy } \\
\text { Strategy }\end{array}$ & $\begin{array}{l}\text { Biofuels Law } \\
\text { (in relation to } \\
\text { Directive } \\
2003 / 30 / \mathrm{EC} \text { ) } \\
\text { (amended in } \\
20089\end{array}$ & $\begin{array}{l}\text { National System } \\
\text { for Energy and } \\
\text { Indoor Air } \\
\text { Quality } \\
\text { Certification of } \\
\text { Buildings (SCE) }\end{array}$ & $\begin{array}{l}\text { Management } \\
\text { System of } \\
\text { Intensive } \\
\text { Energy } \\
\text { Consumption } \\
\text { (SGCIE) }\end{array}$ & $\begin{array}{c}\text { The national } \\
\text { emission } \\
\text { target for } \\
\text { Portugal } \\
\text { under the EU } \\
\text { Effort Sharing } \\
\text { Decision } \\
\text { (406/2009/EC } \\
\text { ) }\end{array}$ & $\begin{array}{l}\text { Managemen } \\
\text { t Structure } \\
\text { of the } \\
\text { National } \\
\text { Energy } \\
\text { Efficiency } \\
\text { Action Plan } \\
\text { (NEEAP) }\end{array}$ & $\begin{array}{c}\text { Public } \\
\text { Contract } \\
\text { Regime } \\
\text { with } \\
\text { Energy } \\
\text { Companies } \\
\text { Services } \\
\text { (ESE) }\end{array}$ \\
\hline & Status & $\square$ & $x$ & $*$ & $\square$ & * & $\square$ & $\square$ & $\square$ & $\square$ \\
\hline & Type & $\begin{array}{l}\text { Regulatory } \\
\text { Instruments }\end{array}$ & $\begin{array}{l}\text { Regulatory } \\
\text { Instrument }\end{array}$ & $\begin{array}{c}\text { Policy } \\
\text { Support/ } \\
\text { Strategic } \\
\text { planning }\end{array}$ & $\begin{array}{c}\text { Policy Support/ } \\
\text { Strategic } \\
\text { planning }\end{array}$ & $\begin{array}{l}\text { Economic } \\
\text { Instrument }\end{array}$ & $\begin{array}{l}\text { Regulatory } \\
\text { Instrument }\end{array}$ & $\begin{array}{l}\text { Regulatory } \\
\text { Instrument }\end{array}$ & $\begin{array}{l}\text { Voluntary } \\
\text { Approach }\end{array}$ & $\begin{array}{l}\text { Policy } \\
\text { Support }\end{array}$ \\
\hline & $\begin{array}{l}\text { Targe } \\
\mathbf{t}\end{array}$ & $\begin{array}{l}\text { Transport } \\
\text { Sector }\end{array}$ & $\begin{array}{c}\text { Multiple } \\
\text { Alternatives }\end{array}$ & $\begin{array}{l}\text { Cross - } \\
\text { Sector }\end{array}$ & Cross - Sector & Buildings & Industry Sector & Cross - Sector & $\begin{array}{l}\text { Transport } \\
\text { Sector }\end{array}$ & Buildings \\
\hline
\end{tabular}


Table A12- Spain Policy Scope: Energy Efficiency; RES and Climate Change Framework between 1990 and 2012 (adapted from: IEA, 2016)

\begin{tabular}{|c|c|c|c|c|c|c|c|c|c|c|}
\hline \multicolumn{11}{|c|}{ Energy Efficiency } \\
\hline \multicolumn{2}{|c|}{ Key Years } & 2006 & 2007 & 2008 & 2009 & 2012 & - & - & - & - \\
\hline \multirow{4}{*}{ 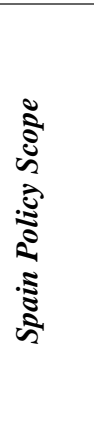 } & Title & $\begin{array}{l}\text { Maritime } \\
\text { Transport } \\
\text { Initiative }\end{array}$ & $\begin{array}{l}\text { Implementation } \\
\text { of the Energy } \\
\text { Performance in } \\
\text { Buildings } \\
\text { Directive }\end{array}$ & $\begin{array}{l}\text { Car } \\
\text { registration } \\
\text { tax linked to } \\
\mathrm{CO} 2 \\
\text { emissions }\end{array}$ & $\begin{array}{l}\text { Automotive } \\
\text { Sector } \\
\text { Competitiveness } \\
\text { Plan }\end{array}$ & $\begin{array}{l}\text { Efficient } \\
\text { Vehicle } \\
\text { Incentives } \\
\text { Programme } \\
\text { (PIVE) }\end{array}$ & - & - & - & - \\
\hline & Status & $\square$ & $\square$ & $\square$ & $\square$ & $\square$ & - & - & - & - \\
\hline & Type & $\begin{array}{l}\text { Economic } \\
\text { Instrument }\end{array}$ & Policy Support & $\begin{array}{l}\text { Regulatory } \\
\text { Instrument }\end{array}$ & $\begin{array}{l}\text { Economic } \\
\text { Instrument }\end{array}$ & $\begin{array}{l}\text { Economic } \\
\text { Instrument }\end{array}$ & - & - & - & - \\
\hline & $\begin{array}{l}\text { Targe } \\
\mathrm{t}\end{array}$ & $\begin{array}{l}\text { Transport } \\
\text { Sector }\end{array}$ & Buildings & $\begin{array}{l}\text { Transport } \\
\text { Sector }\end{array}$ & Transport Sector & $\begin{array}{l}\text { Transport } \\
\text { Sector }\end{array}$ & - & - & - & - \\
\hline \multicolumn{11}{|c|}{ Renewable Energy Sources (RES) } \\
\hline \multicolumn{2}{|c|}{ Key Years } & 1997 & 2005 & 2007 & 2010 & - & - & - & - & - \\
\hline \multirow{4}{*}{ 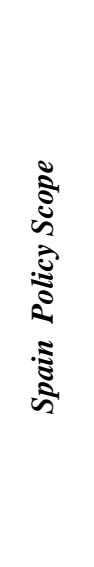 } & Title & $\begin{array}{l}\text { General } \\
\text { Electricity } \\
\text { Law } \\
54 / 1997\end{array}$ & $\begin{array}{l}\text { Renewable } \\
\text { Energy } \\
\text { Plan 2005 - } \\
2010\end{array}$ & $\begin{array}{l}\text { Feed-in } \\
\text { tariffs for } \\
\text { electricity } \\
\text { from } \\
\text { renewable } \\
\text { energy } \\
\text { sources } \\
\text { (Special } \\
\text { regime) }\end{array}$ & $\begin{array}{l}\text { New regulation on } \\
\text { electrical energy } \\
\text { from } \\
\text { wind and thermal } \\
\text { electric } \\
\text { technologies } \\
\text { (Royal Decree } \\
\text { 1614/2010) }\end{array}$ & - & - & - & - & - \\
\hline & Status & * & $x$ & $x$ & $\times$ & - & - & - & - & - \\
\hline & Type & $\begin{array}{l}\text { Regulatory } \\
\text { Instrument }\end{array}$ & $\begin{array}{l}\text { Economic } \\
\text { Instrument }\end{array}$ & $\begin{array}{l}\text { Economic } \\
\text { Instrument }\end{array}$ & $\begin{array}{l}\text { Regulatory } \\
\text { Instrument }\end{array}$ & - & - & - & - & - \\
\hline & $\begin{array}{l}\text { Targe } \\
\mathrm{t}\end{array}$ & $\begin{array}{l}\text { Multiple } \\
\text { Alternatives }\end{array}$ & $\begin{array}{l}\text { Multiple } \\
\text { Alternatives }\end{array}$ & $\begin{array}{l}\text { Multiple } \\
\text { Alternatives }\end{array}$ & Wind Power & - & - & - & - & - \\
\hline \multicolumn{2}{|c|}{ Key Years } & \multicolumn{9}{|c|}{ Climate Change } \\
\hline \multirow{2}{*}{ 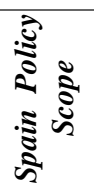 } & & 2004 & 2005 & 2007 & 2008 & 2009 & 2011 & 2012 & - & 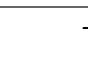 \\
\hline & Title & $\begin{array}{l}\text { Adoption of } \\
\text { the }\end{array}$ & $\begin{array}{l}\text { Energy } \\
\text { Efficiency } \\
\text { Action }\end{array}$ & $\begin{array}{l}\text { Implementat } \\
\text { ion }\end{array}$ & $\begin{array}{l}\text { The Spanish } \\
\text { National Climate } \\
\text { Change }\end{array}$ & $\begin{array}{l}\text { The national } \\
\text { emission target } \\
\text { for Spain under }\end{array}$ & $\begin{array}{l}\text { Sustainable } \\
\text { Economy Law }\end{array}$ & $\begin{array}{l}\text { Efficient } \\
\text { Vehicle } \\
\text { Incentives }\end{array}$ & - & 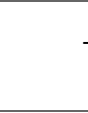 \\
\hline
\end{tabular}




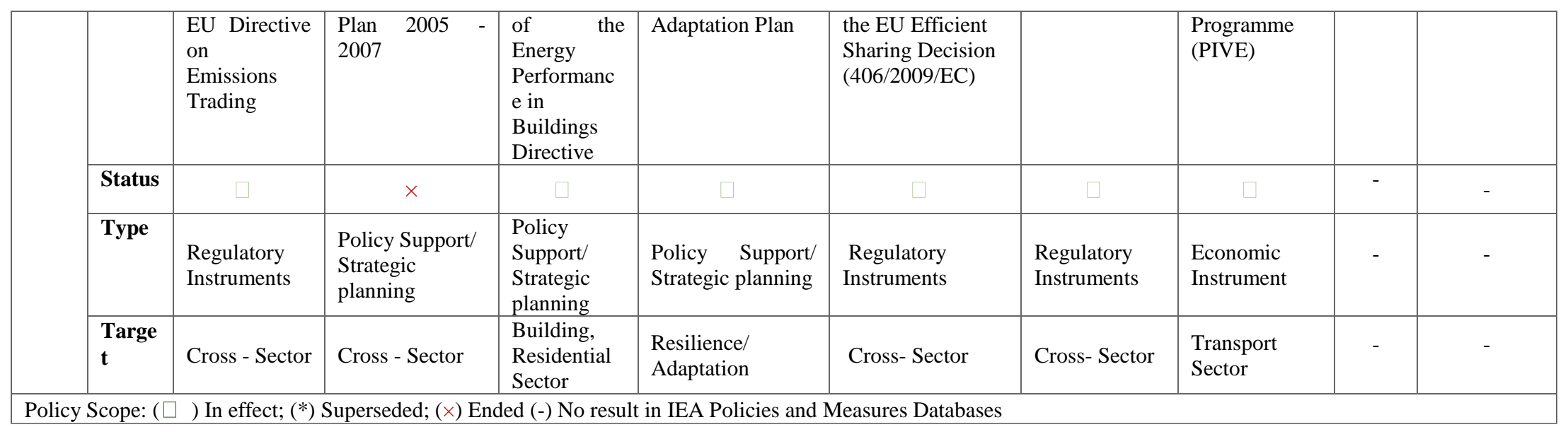

